ESRI

RESEARCH

SERIES

NUMBER 62

May 2017

\section{FAMILY REUNIFICATION OF NON-EU NATIONALS IN IRELAND}

SAMANTHA ARNOLD AND EMMA QUINN

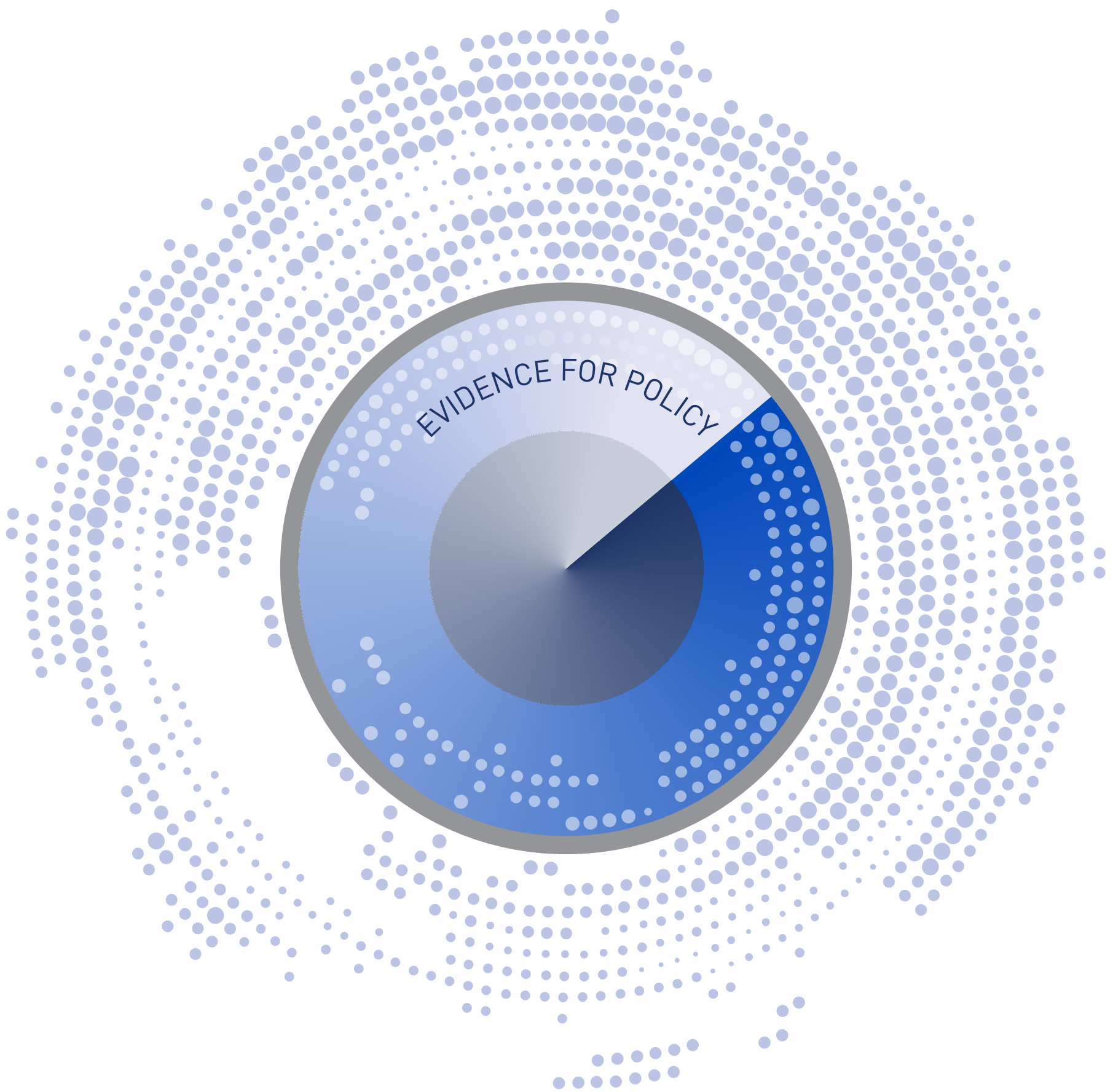




\title{
FAMILY REUNIFICATION OF NON-EU NATIONALS IN IRELAND
}

\author{
Samantha Arnold
}

Emma Quinn

May 2017

\section{RESEARCH SERIES}

\section{NUMBER 62}

Study completed by the Irish National Contact Point of the European Migration Network (EMN) which is financially supported by the European Union and the Irish Department of Justice and Equality. The EMN has been established via Council Decision 2008/381/EC.

Available to download from www.emn.ie

The Economic and Social Research Institute

Whitaker Square, Sir John Rogerson's Quay, Dublin 2 


\section{THE EUROPEAN MIGRATION NETWORK}

The aim of the European Migration Network (EMN) is to provide up-to-date, objective, reliable and comparable information on migration and asylum at Member State and EU levels with a view to supporting policymaking and informing the general public.

The Irish National Contact Point of the European Migration Network, EMN Ireland, sits within the Economic and Social Research Institute (ESRI).

\section{ABOUT THE ESRI}

The mission of the Economic and Social Research Institute is to advance evidencebased policymaking that supports economic sustainability and social progress in Ireland. ESRI researchers apply the highest standards of academic excellence to challenges facing policymakers, focusing on 12 areas of critical importance to 21st Century Ireland.

The Institute was founded in 1960 by a group of senior civil servants led by Dr T.K. Whitaker, who identified the need for independent and in-depth research analysis to provide a robust evidence base for policymaking in Ireland.

Since then, the Institute has remained committed to independent research and its work is free of any expressed ideology or political position. The Institute publishes all research reaching the appropriate academic standard, irrespective of its findings or who funds the research.

The quality of its research output is guaranteed by a rigorous peer review process. ESRI researchers are experts in their fields and are committed to producing work that meets the highest academic standards and practices.

The work of the Institute is disseminated widely in books, journal articles and reports. ESRI publications are available to download, free of charge, from its website. Additionally, ESRI staff communicate research findings at regular conferences and seminars.

The ESRI is a company limited by guarantee, answerable to its members and governed by a Council, comprising 14 members who represent a cross-section of ESRI members from academia, civil services, state agencies, businesses and civil society. The Institute receives an annual grant-in-aid from the Department of Public Expenditure and Reform to support the scientific and public interest elements of the Institute's activities; the grant accounted for an average of 30 per cent of the Institute's income over the lifetime of the last Research Strategy. The remaining funding comes from research programmes supported by government departments and agencies, public bodies and competitive research programmes.

Further information is available at www.esri.ie. 


\section{THE AUTHORS}

Samantha Arnold is a Post-Doctoral Research Fellow at the Irish National Contact Point of the European Migration Network (EMN). Emma Quinn is Head of the Irish National Contact Point of the European Migration Network (EMN), within the Economic and Social Research Institute (ESRI).

\section{ACKNOWLEDGEMENTS}

In compiling this study valuable assistance was received from officials of the Irish Naturalisation and Immigration Service and United Nations High Commission for Refugees Ireland. Thanks are also due to representatives of the Immigrant Council of Ireland (ICI), Nasc and Crosscare Migrant Project.

We also acknowledge the useful comments and suggestions received from our colleagues and the referees.

Finally, thanks are also due to our colleagues Elaine Byrne and Sarah Burns at the ESRI. We are grateful to everyone who shared their expertise with us for the purpose of writing this study.

\section{ABOUT THIS REPORT}

This European Migration Network study examines family reunification policy, law and practice in Ireland, considering recent changes in law and guidance. The study focuses on rules governing family reunification for non-EEA citizens. The report consists of information gathered by way of a common template, primarily for an overview, EU-level synthesis report, Family Reunification of TCNs in the EU: National Practice.

This report has been accepted for publication by the Institute, which does not itself take institutional policy positions. All ESRI Research Series reports are peer reviewed prior to publication. The authors are solely responsible for the content and the views expressed and do not represent the position of the Economic and Social Research Institute, the Irish Naturalisation and Immigration Service, the Department of Justice and Equality, or the European Commission, Directorate-General Migration and Home Affairs. 


\section{TABLE OF CONTENTS}

EXECUTIVE SUMMARY

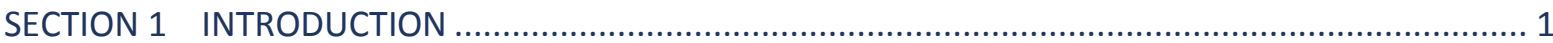

1.1 Objectives and background to the study …............................................................. 1

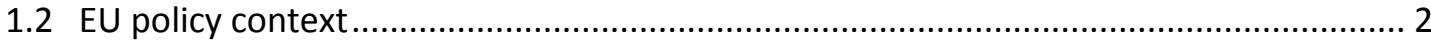

1.3 Overview of main trends regarding family reunification in Europe................................ 3

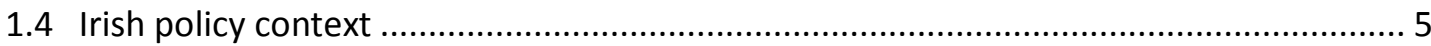

1.5 Overview of main trends regarding family reunification in Ireland ................................. 7

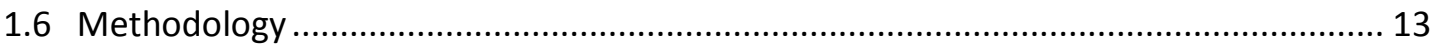

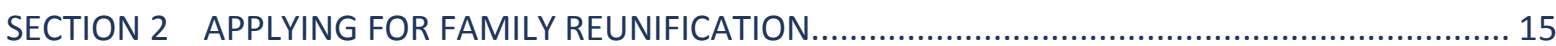

2.1 Introduction: general overview of application procedure ........................................... 15

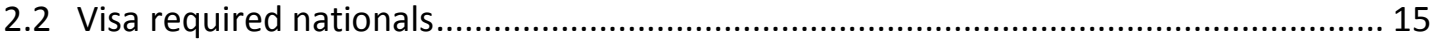

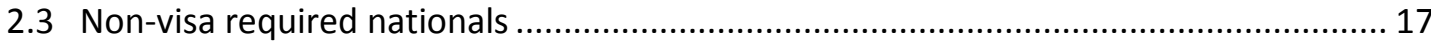

2.4 Family formation/change of family circumstances ..................................................... 17

2.5 Beneficiaries of international protection ................................................................ 18

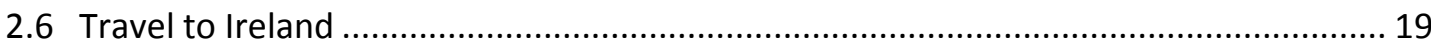

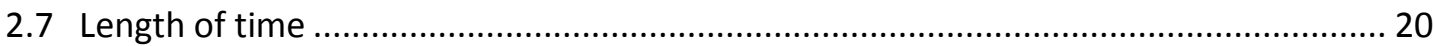

2.8 Challenges to accessing the process of family reunification .......................................... 21

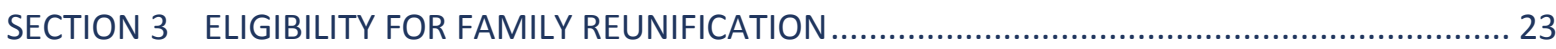

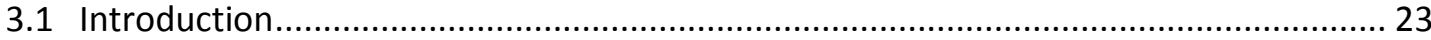

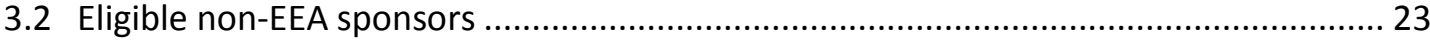

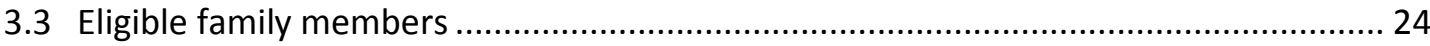

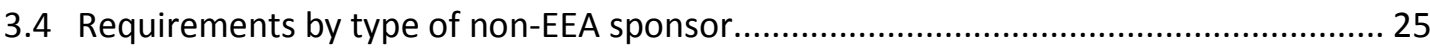

$\begin{array}{lll}3.4 .1 & \text { Financial criteria } & 25\end{array}$

$\begin{array}{lll}\text { 3.4.2 Elderly dependent parents } & 28\end{array}$

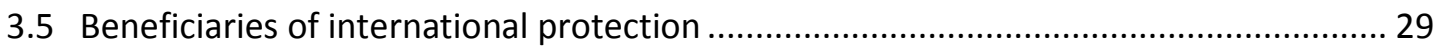

3.5.1 Dependent family members of beneficiaries of international protection $\quad 30$

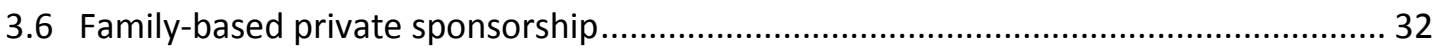

3.7 Ineligibility: rejection on grounds of public policy, security and health ........................ 32

3.7.1 Ineligibility in the context of international protection 34

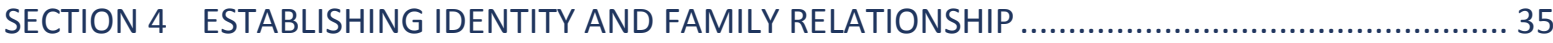

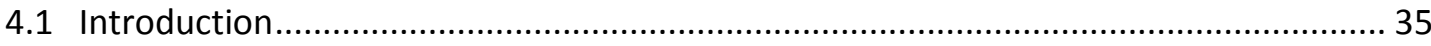

4.2 Relationship history: spouses and de facto partners .................................................. 37 


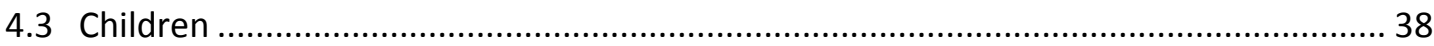

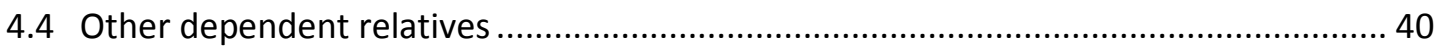

4.5 Family members of beneficiaries of international protection ....................................... 42

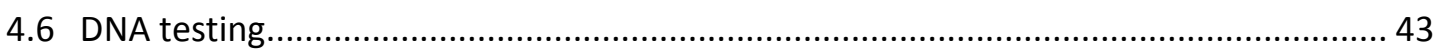

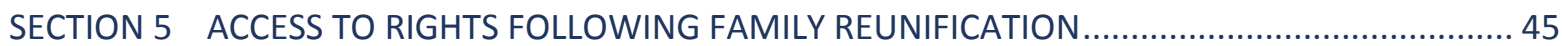

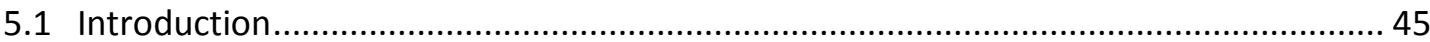

5.2 Integration in employment, housing, education and health ........................................ 46

5.2.1 Labour market 46

$\begin{array}{lll}\text { 5.2.2 Education and vocational education } & 47\end{array}$

5.2.3 Social welfare, public health care and housing 48

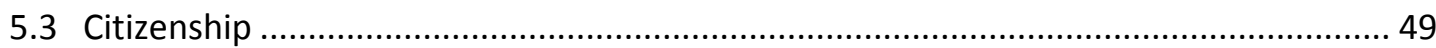

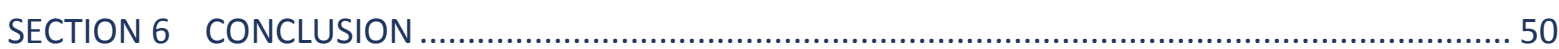

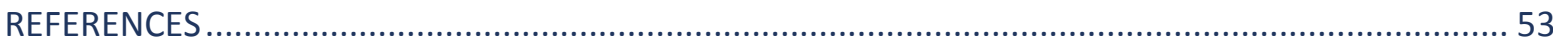

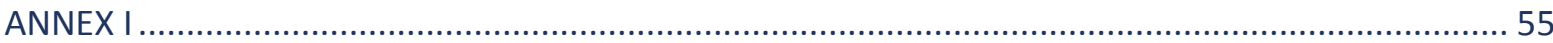

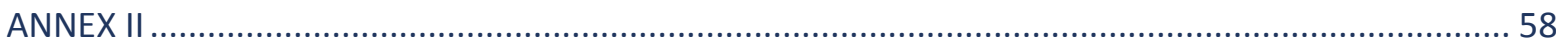

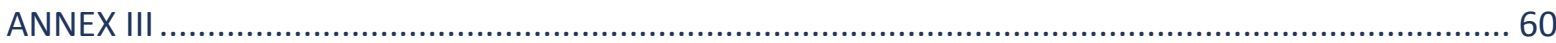




\section{LIST OF TABLES}

Table 1.1 Family reunification applications, grants and refusals (data refer to family members who are the subjects of family reunification applications) 2011-2016

Table 2.1 Persons assisted to travel to Ireland under the Travel Assistance Scheme ..................20

Table 3.1 Family Income Supplement weekly income limits 2016/2017 ....................................26

Table 4.1 Documentary evidence required to confirm identity of family members and family relationship with sponsor

Table A1.1 Applications for family reunification by individual family member of beneficiary of international protection sponsor, 2011-2016.

Table A1.2 Successful applications for family reunification by individual family member of beneficiary of international protection sponsor, 2011-2016

Table A1.3 Rejected applications for family reunification by individual family member of beneficiary of international protection sponsor, 2011-2016

Table A1.4 Applications for family reunification by application from beneficiary of international protection sponsor, 2011-2016

Table A1.5 Successful applications for family reunification by application from beneficiary of international protection sponsor, 2011-2016

Table A1.6 Rejected applications for family reunification by application from beneficiary of international protection sponsor, 2011-2016 ….......................................................... 57

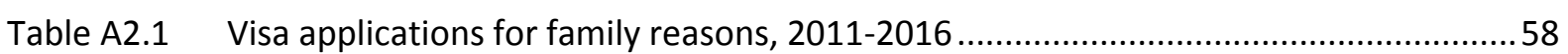

Table A2.2 Visa applications for family reasons granted, 2011-2016 ….......................................58

Table A2.3 Visa applications for family reasons rejected, 2011-2016 ...........................................59

Table A3.1 Top ten nationalities of applicant family members for visas for family reasons, 2016

Table A3.2 Top ten nationalities of persons granted visas for family reasons, 2016 ....................60

Table A3.3 Top ten nationalities of persons refused visas for family reasons, 2016 .....................61

\section{LIST OF FIGURES}

Figure 1.1 First residence permits issued by reason per year EU28, 2011-2015

Figure 1.2 Percentage of first permits issued for family reasons out of total first permits EU28 plus Norway (2011-2015)

Figure 1.3 First permits issued for family reasons in top eight Member States (2011-2015) ..........5

Figure 1.4 Non-EEA residence permits valid in Ireland (Non-EEA nationals aged 16 and over) 2011-2015

Figure 1.5 Non-EEA residence permits valid in Ireland in 2015: beneficiaries of international protection and other all other permit holders.

Figure 1.6 Visa applications for family reasons in Ireland, 2011-2016........................................ 11

Figure 1.7 Visa applications for family reasons granted in Ireland, 2011-2016 ............................12

Figure 1.8 Nationalities of persons granted visas for family reasons, 2016 (non-EEA sponsors) ..13 


\section{ABBREVIATIONS}

DFAT

DJE

DSP

EC

EEA

EMN

ESRI

EROC

EU

GP

ICRC

INIS

IOM

IRPP

NASC

NGO

MIPEX

OPMI

SHAP

TCN

UNHCR
Department of Foreign Affairs and Trade

Department of Justice and Equality

Department of Social Protection

European Commission

European Economic Area

European Migration Network

Economic and Social Research Institute

Emergency Reception and Orientation Centres

European Union

General Practitioner

International Committee of the Red Cross

Irish Naturalisation and Immigration Service

International Organization for Migration

Irish Refugee Protection Programme

Irish Immigrant Support Centre

Non-governmental Organisation

Migrant Integration Policy Index

Office for the Promotion of Migrant Integration

Syrian Humanitarian Admission Programme

Third Country National

Office of the United Nations High Commissioner for Refugees 


\section{EXECUTIVE SUMMARY}

Joining family is among the myriad reasons for migration, accounting for 30 per cent of all permanent migration into OECD countries in 2015 (OECD 2016). The right to family, or family unity, is a principle enshrined in international, European and domestic law.

Family reunification promotes the integration of migrants already in the host country (INIS, 2016a; UNHCR, 2013). The EU Directive on the right to family reunification states that it helps to create socio-cultural stability, facilitating integration and promoting economic and social cohesion. Family reunification is also central to the protection mandate of UNHCR as it is fundamental to ensuring the protection and wellbeing of the individual family members and the integration of refugees (UNHCR, 2001). Family reunification is often a feature of national immigration systems used to attract highly skilled migrants. For example, research identifies the absence of clearly defined family reunification as a possible barrier to attracting non-EEA ${ }^{1}$ nationals to Ireland (Quinn and Gusciute, 2013).

The purpose of this study is to analyse family reunification policy, law and practice in Ireland, considering recent changes in law and guidance. The study focuses on rules governing family reunification for non-EEA citizens. Some comparisons are drawn between the EU context and the Irish context where relevant.

The best available data on the 'stock' of non-EEA family members in Ireland are residence permits issued for family-related reasons. In 2015, 25,632 residence permits were held in Ireland by non-EEA family members, representing 23 per cent of total permits held. In the EU as a whole, family members accounted for 38 per cent of total residence permits held in the same year. Residence permits issued for the first time provide information on the 'flow' of family members coming Ireland for the first time. In 2015, 3,444 such permits were issued in Ireland, representing 9 per cent of the 38,433 of first permits issued. First residence permits issued for family-related reasons represented the smallest category of permits issued, coming after education, employment and other. In contrast permits issued for family-related reasons formed the largest category of permits issued in the EU, accounting for 29 per cent of total new permits issued. 
Data on family reunification applications are only available for the subset of beneficiaries of international protection: in 2016 applications were made in respect of 756 family members of refugees and 406 were approved. Based on the relative size of the populations that sponsors could potentially be drawn from, we can assume that the group of family members of non-beneficiaries is larger than the group of family members of beneficiaries of international protection.

Non-EEA family reunification at the EU level is governed by Council Directive 2003/86/EC of 22 September 2003 on the right to family reunification (Directive) in all Member States except Denmark, Ireland and the United Kingdom. In Ireland, family reunification for beneficiaries of international protection is governed by the International Protection Act 2015 and for all other non-EEA nationals by the INIS Policy Document on Non-EEA Family Reunification. Non protection-related family reunification operates largely on the basis of Ministerial discretion. Although Ireland did not exercise its right to opt in to the Directive, it has been referenced in High Court judgments.

While most non-EEA nationals may apply for family reunification in Ireland, the criteria and application processes differ depending on the residence permission of the sponsor. It is the responsibility of sponsors to satisfy INIS that the level of income or financial resources is sufficient for sponsorship. The INIS Policy Document provides for the exercise of discretion on the part of the decisionmaker when balancing competing elements of the application.

Access to family reunification in Ireland has been criticised, in research literature and by non-governmental organisations. Significant changes to procedures were introduced in 2014, when the new Policy Document on Non-EEA Family Reunification became operational (revised in 2016) (INIS, 2016a). The last major study on family reunification was undertaken by the Immigrant Council of Ireland in 2012, which observed long delays in processing applications, concerns relating to the lack of a legal entitlement to family reunification, and the low approval rate. This is the first comprehensive study on family reunification in Ireland since 2012. It takes account of the Policy Document as well as the recent commencement of the International Protection Act 2015, which introduced significant changes to family reunification law for beneficiaries of international protection. It also reflects other important changes arising from court decisions.

NGOs argue that, on the one hand, a lack of a legislative entitlement to reunification and the reliance on discretion has resulted in inconsistencies in decision-making. On the other hand, NGOs and decision-makers noted that 
discretionary decision-making may benefit the applicant; for example income requirements may be waived on a case-by-case basis.

Prior to the International Protection Act 2015 which replaced the Refugee Act 1996, family reunification for beneficiaries of international protection in Ireland was seen as more generous than the Directive. The Act of 2015 brought about significant changes, removing the pre-existing category of dependent relatives and narrowing eligibility to spouses and children (and minor siblings in applications by unaccompanied minors). In the past dependent family members, including grandparents, parents, brothers, sisters, grandchildren, and guardians were eligible pursuant to Section 18(4) of the Refugee Act 1996. The removal of this category in the Act of 2015 has been met with concern from NGOs and UNHCR.

Under the Act of 2015, beneficiaries of subsidiary protection are entitled to family reunification in the same way as refugees. Not all Member States extend the right to family reunification to beneficiaries of subsidiary protection (European Migration Network, 2017). In addition applications must be made within 12 months of a grant of international protection. The equivalent provision under the Family Reunification Directive allows for Member States to apply a limit of three months.

INIS and NGOs noted that applications for family reunification are labour intensive to process. INIS expressed the view that the changes in respect of beneficiaries of international protection, namely the new 12-month time limit within which to apply and the narrower definition of family member, will speed up the process in part by reducing the number of applications received. ${ }^{2}$ NGOs reported increased requests for support from persons applying to be joined by family in 2016. They also observed that no targeted legal service exists. Applicant family members and sponsors can encounter a number of difficulties providing adequate evidence to support their application, relating to gathering documents from the country of origin and fulfilling DNA testing requirements (where applicable).

NGOs emphasised the importance of providing orientation and integration supports for families and sponsors to overcome some of the initial challenges arising from protracted periods of separation, cultural differences, language competence and access to adequate housing. While no targeted integration support measures are in place for family members, depending on the status of their sponsor, they may access mainstream services. 


\section{SECTION 1}

\section{Introduction}

\subsection{OBJECTIVES AND BACKGROUND TO THE STUDY}

Joining family is among the myriad reasons for migration, accounting for 30 per cent of all permanent migration into OECD ${ }^{3}$ countries in 2015 (OECD 2016). ${ }^{4}$ Family migration can encompass family reunification, family formation and migration of an entire family at the same time (European Migration Network, 2014 , p. 126). Family reunification can present challenges within a managed migration policy framework. Legally residing immigrants hold certain rights and entitlements, which are particularly strong in the case of beneficiaries of international protection.

The right to family, or family unity, is a principle enshrined in international, European and domestic law. The Universal Declaration of Human Rights 1948 (Article 16.3) and the International Covenant on Civil and Political Rights 1966 (Article 23.1) describe the family as 'the natural and fundamental group unit of society and notes that it is entitled to protection by society and the State'. The European Convention on Human Rights (Article 8) provides that 'everyone has the right to respect for his private and family life, his home and his correspondence'. In Ireland Bunreacht na hÉireann (Irish Constitution) (Article 41)

recognises the Family as the natural primary and fundamental unit group of Society, and as a moral institution possessing inalienable and imprescriptible rights, antecedent and superior to all positive law.

Family reunification promotes the integration of migrants already in the host country (INIS, 2016a; UNHCR, 2013). ${ }^{5}$ The EU Directive on the right to family reunification ${ }^{6}$ states that it helps to create socio-cultural stability, facilitating integration and promoting economic and social cohesion. Family reunification is also central to the protection mandate of UNHCR as it is fundamental to ensuring the protection and wellbeing of the individual family members and the integration of refugees (UNHCR, 2001). Family reunification is often a feature of national immigration systems used to attract highly skilled migrants. For example, research identifies the absence of clearly defined family reunification as a

Organisation for European Economic Co-operation and Development.

Members of OECD: Australia, Austria, Belgium, Canada, Chile, Czech Republic, Denmark, Estonia, Finland, France, Germany, Greece, Hungary, Iceland, Ireland, Israel, Italy, Japan, Korea, Latvia, Luxembourg, Mexico, Netherlands, New Zealand, Norway, Poland, Portugal, Slovak Republic, Slovenia, Spain, Sweden, Switzerland, Turkey, United Kingdom, United States.

European Commission Migration and Home Affairs, 'Family reunification' https://ec.europa.eu.

Council Directive 2003/86/EC of 22 September 2003 on the right to family reunification, Preamble, Recital 4. 
possible barrier to attracting non-EEA nationals to Ireland (Quinn and Gusciute, 2013).

The purpose of this study is to analyse family reunification policy, law and practice in Ireland, considering recent changes in law and guidance. The study focuses on rules governing family reunification for non-EEA citizens. Some comparisons are drawn between the EU context and the Irish context where relevant.

Section 2 describes the application process. Section 3 provides information on eligible sponsors, eligible family members and the application procedure. Section 4 outlines the requirements for establishing identity and family relationships as part of the process of applying for family reunification in Ireland. Section 5 describes the rights and entitlements that flow from permission to remain in Ireland for family reasons, specifically family members' access to the labour market; education and vocational training; social welfare, public health care and housing; and naturalisation. Key findings from the study are reviewed in Section 6.

\subsection{EU POLICY CONTEXT}

In the EU context, family reunification is defined as

the entry into and residence in a Member State by family members of a third country national residing lawfully in that Member State in order to preserve the family unit, whether the family relationship arose before or after the resident's entry. ${ }^{7}$

Family formation refers to families that are established either with a thirdcountry national sponsor who has already gained legal residence in a Member State or with an EU national (European Migration Network, 2014, p. 124). Policy, procedure and law relating to family reunification and family formation in respect of non-EEA nationals is governed by Council Directive 2003/86/EC of 22 September 2003 on the right to family reunification (hereafter the Directive) in all Member States except Denmark, Ireland and the United Kingdom. ${ }^{8}$ The Directive lays down the conditions for the exercise of the right to family reunification by third-country nationals residing lawfully in the territory of the Member States. The Directive determines the conditions under which family members can enter and reside in a Member State in order to preserve the family unit. Member States are obliged to authorise entry and residence for an applicant's spouse and 
unmarried children. Member States are given discretion to authorise entry and residence for other family members. The European Commission in its first implementation report ${ }^{9}$ in 2008 concluded that the Directive has had relatively little impact at EU level and has not resulted in significant harmonisation in practice across Europe (European Commission, 2008).

\subsection{OVERVIEW OF MAIN TRENDS REGARDING FAMILY REUNIFICATION IN EUROPE}

Figure 1.1 shows that family reasons account for the largest proportion of first residence permissions ${ }^{10,11}$ issued in EU28 countries in 2015 (29 per cent of the total). First residence permissions for family reasons account for the largest proportion of all permissions issued for the first time annually between 2011 and 2015. The number of first residence permissions issued for family reasons increased by about 11 per cent year-on-year between 2014 and 2015 (680,388 to $753,377)$.

\section{FIGURE 1.1 FIRST RESIDENCE PERMITS ISSUED BY REASON PER YEAR EU28, 2011-2015}

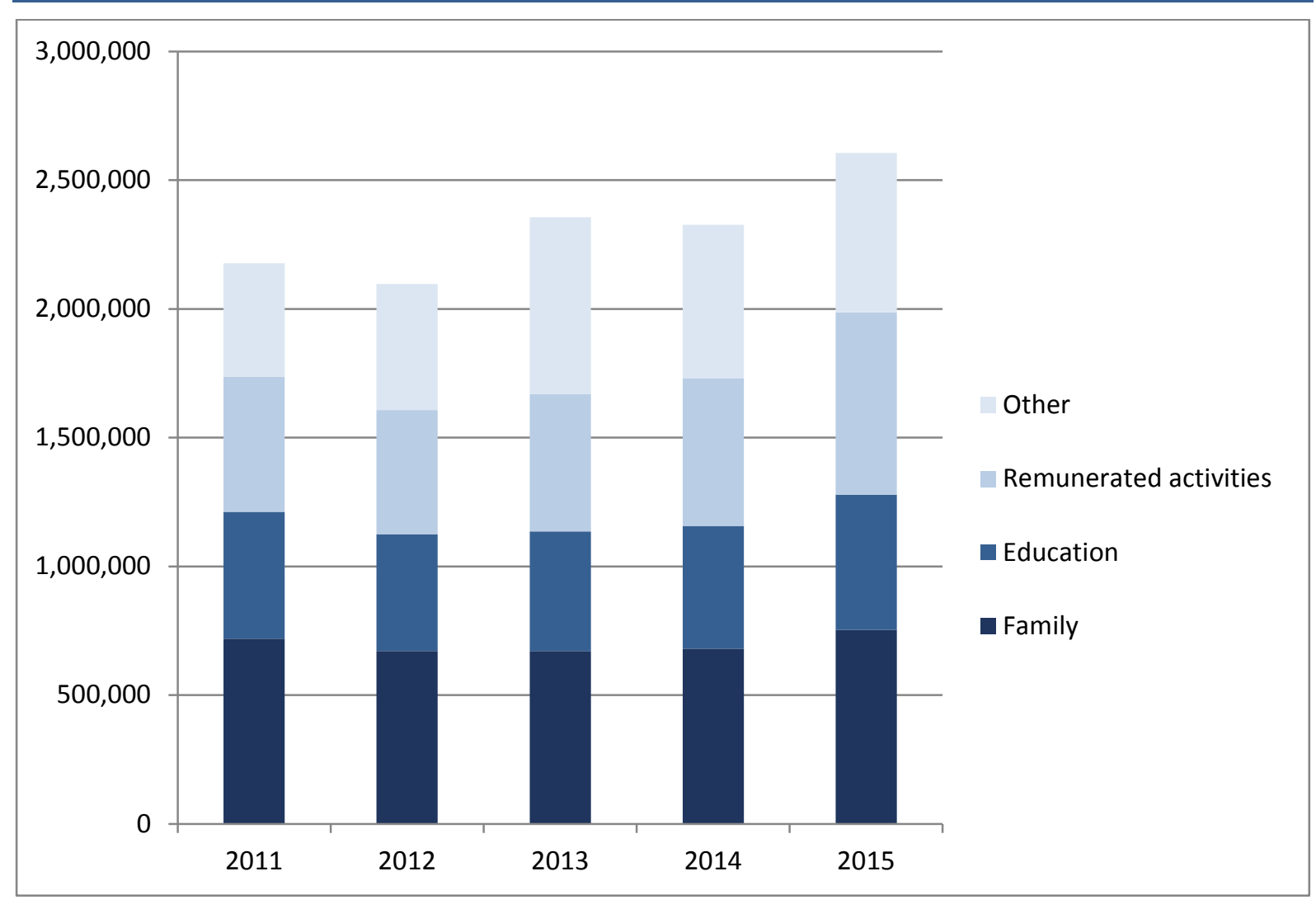

Source: Eurostat [migr_resfirst]. 
Figure 1.2 shows that Poland ( 1 per cent) and Ireland ( 7 per cent) recorded the lowest proportion of first permits issued for family reasons between 2011 and 2015. Figure 1.3 shows that Spain, Italy, the UK, France, Sweden, Belgium and the Netherlands issued the highest number of first permits for family reasons in EU28. Croatia recorded the largest proportion of first permits between 2011 and 2015 (59 per cent) ${ }^{12}$ followed by Greece and Luxembourg (58 per cent). Figure 1.3 shows the share of first permits issued for family reasons in the top eight EU Member States between 2011 and 2015.

FIGURE 1.2 PERCENTAGE OF FIRST PERMITS ISSUED FOR FAMILY REASONS OUT OF TOTAL FIRST PERMITS EU28 PLUS NORWAY (2011-2015)

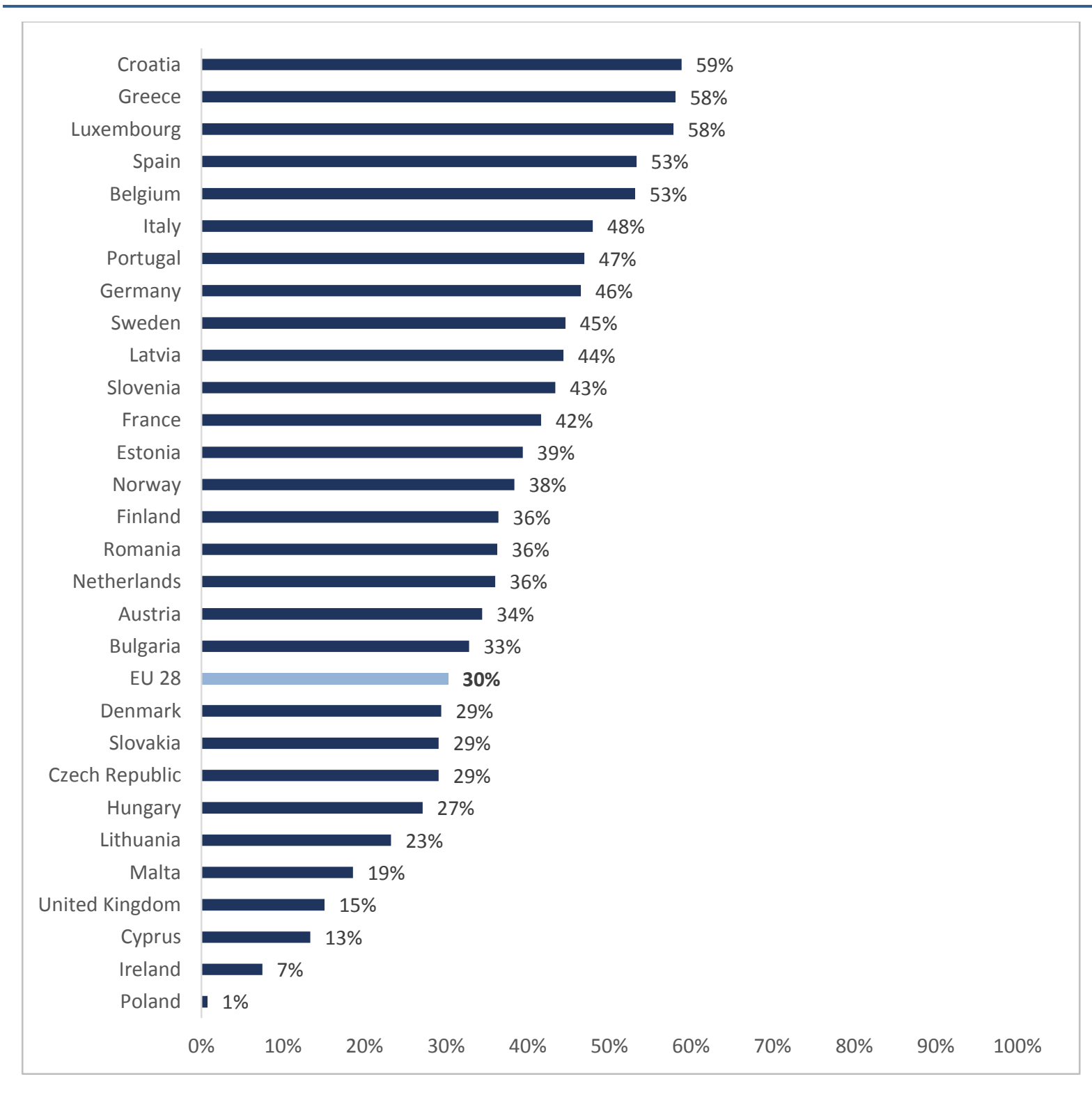

Sources: Eurostat [migr_resfirst]; EMN 2017.

Note: $\quad$ No data were recorded for Croatia in the years 2011 and 2012. No data recorded for Switzerland in 2011 and 2015.

12 No data were recorded for Croatia in the years 2011 and 2012. 


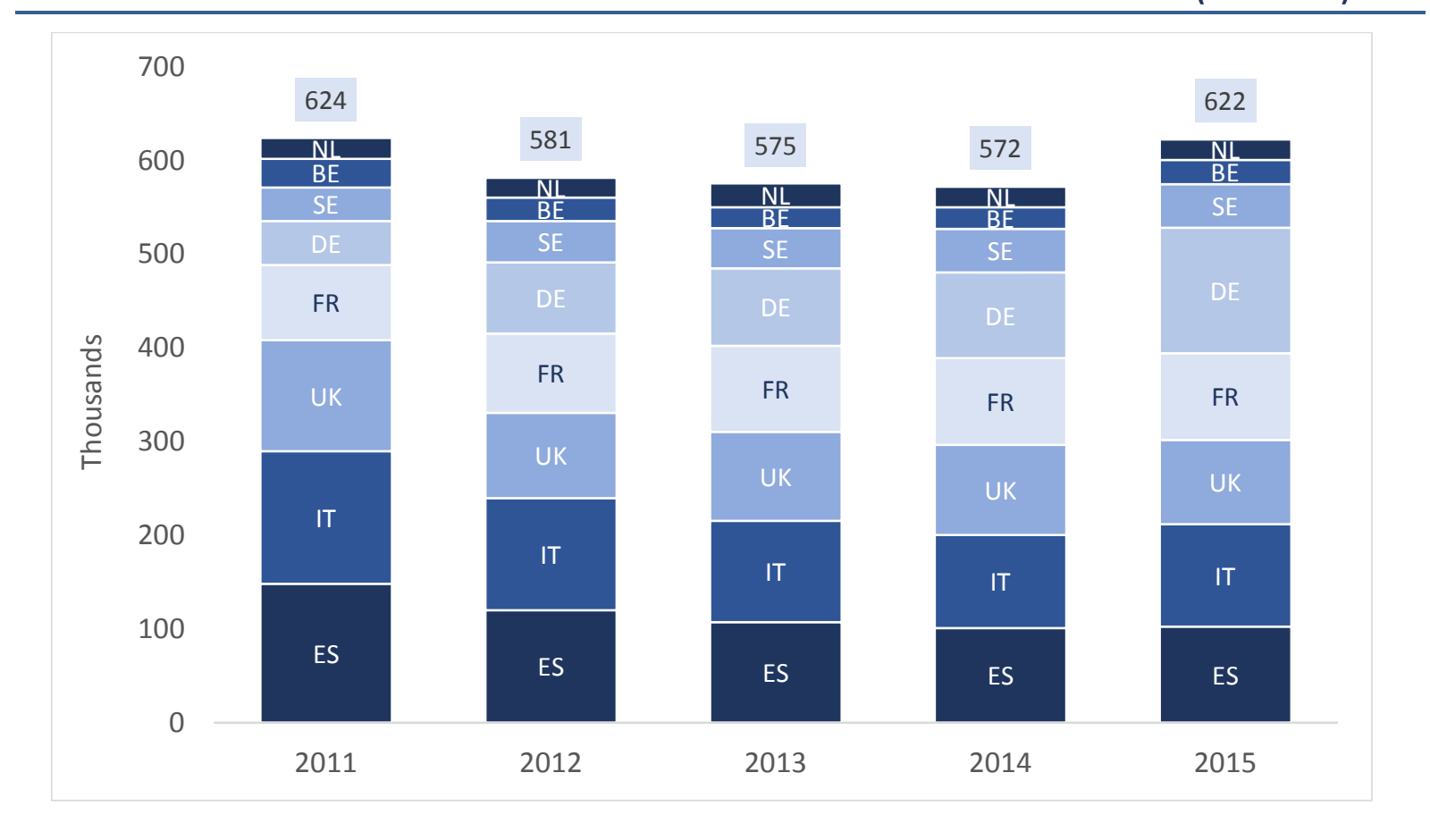

Sources: Eurostat [migr_resfirst]; EMN 2017.

\section{$1.4 \quad$ IRISH POLICY CONTEXT}

NGOs and IGOs argue that family reunification promotes the integration ${ }^{13}$ of family already in the host country (Finn, 2017; UNHCR, 2001). The Policy Document on Non-EEA Family Reunification (Policy Document) notes that 'It is considered as a matter of policy that family reunification contributes towards the integration of foreign nationals in the State.' Family reunification does not form part of the recently published Migrant Integration Strategy (Department of Justice and Equality, 2017).

While most ${ }^{14}$ non-EEA nationals may apply for family reunification, the criteria and application processes differ depending on the residence permission of the sponsor.

Family reunification and family formation applications made by non-EEA nationals (not including beneficiaries of international protection who fall under the International Protection Act, 2015) are governed by the Irish Naturalisation and Immigration Service (INIS) Policy Document (2016a). Legislation governs the access of beneficiaries of international protection (specifically Geneva Convention refugees, Programme Refugees ${ }^{15}$ and beneficiaries of subsidiary protection) to 
family reunification. Ireland exercised its right to opt-in to Council Directive 2004/83, referred to as the Qualification Directive, Article 23 of which provides for the right to family unity for beneficiaries of international protection. ${ }^{16}$ Applications from beneficiaries of international protection are processed pursuant to the International Protection Act, 2015. Prior to January 2016 such applications were processed under Section 18 of the Refugee Act 1996 and S.I. 426 of 2013 in relation to subsidiary protection beneficiaries. ${ }^{17}$ Not all Member States extend the right to family reunification to beneficiaries of subsidiary protection. Beneficiaries of subsidiary protection do not fall within the scope of the Family Reunification Directive (European Migration Network 2017).

The Policy Document and the Act of 2015 provide information on persons eligible (see Section 3), the use of discretion (see Sections 3 and 4) and the requirements and relevant criteria applied in the procedure and the decision-making process (see Section 4).

Family reunification operates on the basis of ministerial discretion in all cases except those concerning nuclear family members of beneficiaries of international protection. Non-governmental organisations (NGO) and researchers have criticised the lack of clarity on eligibility and the application processes in the past. However INIS published the Policy Document in December 2013 with a view to providing more detail on family reunification policy and how discretion is applied (INIS, 2016a). The Policy Document became operational in $2014^{18}$ and it was revised in 2016 (INIS, 2016a). A number of recent High Court cases have provided further clarification on some aspects of family reunification (see Section 4). In addition the International Protection Act, 2015, commenced at the end of 2016, reformed family reunification for beneficiaries of international protection. This was accompanied by the publication of new guidance for beneficiaries of international protection applying for family reunification (INIS, 2016b).

As mentioned above, Ireland did not exercise its right to opt in to the Directive. However it has been referenced in High Court judgments. Hamza is an Irish High Court case of importance for this study as it provides a link between the Directive and practice in Ireland. In Hamza, J. Cooke held that although Ireland did not opt in to the Directive, Section 18 of the Refugee Act should be construed harmoniously with the Directive insofar as possible:

given by the Government or the Minister and whose name is entered in a register established and maintained by the Minister, whether or not such person is a refugee within the meaning of the definition of "refugee"'. 
The rationale of family reunification as an objective in this area is well expressed in Recital (4) to the Council Directive:

'Family reunification is a necessary way of making family life possible. It helps to create socio-cultural stability facilitating the integration of third country nationals in the Member State, which also serves to promote economic and social cohesion, a fundamental Community objective stated in the Treaty.'

Notwithstanding the non-binding nature of these sources, it is desirable in the view of the Court, that the provisions of $S .18$ should be construed and applied so far as statutory interpretation permits in a manner which is consistent with these policies and with the consensus apparent among the Member States of the Union in the objectives of the Council Directive. ${ }^{19}$

The decision of the High Court in Hamza was subsequently upheld by the Supreme Court (see Section 4 for more cases that refer to the Directive). ${ }^{20}$ This case interpreted Section 18 of the Refugee Act 1996. The Refugee Act 1996 preceded the International Protection Act 2015 and is no longer applicable.

In 2015 the Migrant Integration Policy Index (MIPEX), which provides on-going assessment of policies with a view to assessing, comparing and improving integration policy indicators (Huddleston et al., 2015; Barrett et al., 2017), described Ireland's family reunification policies as 'some of the least familyfriendly in the developed world'.

\subsection{OVERVIEW OF MAIN TRENDS REGARDING FAMILY REUNIFICATION IN IRELAND}

The best available data on the 'stock' of non-EEA family members in Ireland are residence permits issued for family-related reasons. In 2015, 25,632 residence permits were held in Ireland by non-EEA family members, representing 23 per cent of total permits held. ${ }^{21}$ Figure 1.4 shows that the total residence permits valid in Ireland for education reasons accounted for the largest proportion $(194,245)$ of the total 575,303 permits between 2011 and 2015. The share of all valid permissions issued for education reasons increased from 28 per cent in $2011(35,493)$ to 38 per cent in $2015(43,540)$, perhaps in part reflecting the renewed focus on encouraging international students to study in Ireland (Barrett et al., 2017).

\footnotetext{
Hamza \& Anor v. The Minister for Justice, Equality and Law Reform [2010] IEHC 427 at 31-34. Hamza v Minister for Justice [2013] IESC 9.

Note that the category 'other' could also contain family-related residence permits.
} 
Figure 1.4 shows that the total valid residence permits ${ }^{22}$ issued for family reasons increased annually between 2011 and 2015 (with a small decrease between 2012 and 2013).

Overall valid permits issued for family reasons increased from 17 per cent $(21,906)$ of the total 128,104 permits in Ireland in 2011 to 23 per cent $(25,632)$ of 113,914 issued in 2015. In comparison residence permits issued for family-related reasons accounted for 38 per cent of the total permits issued in the EU in 2015.

FIGURE 1.4 NON-EEA RESIDENCE PERMITS VALID IN IRELAND (NON-EEA NATIONALS AGED 16 AND OVER) 2011-2015

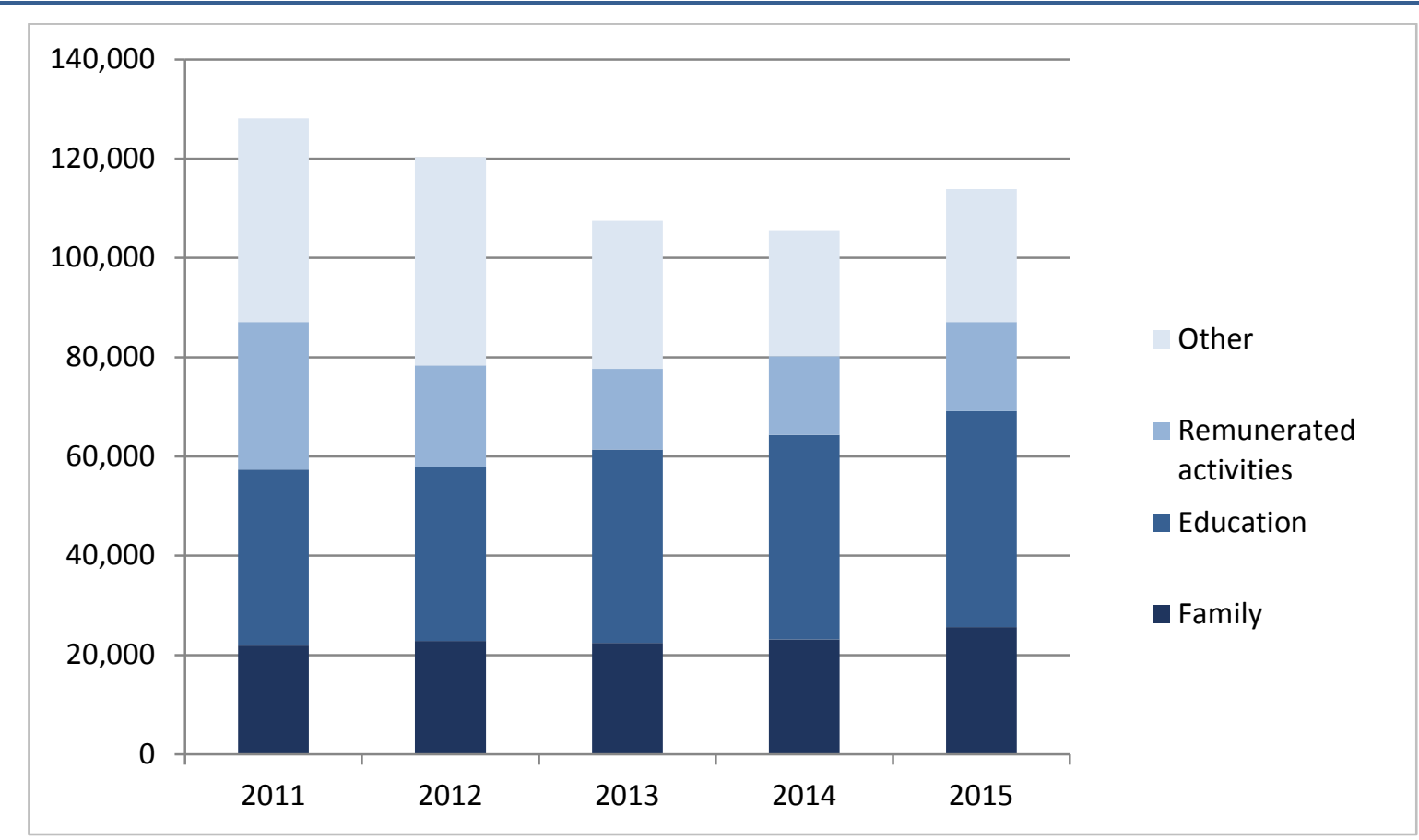

Source: Eurostat [migr_ressvalid].

Residence permits issued for the first time provide information on the 'flow' of family members coming Ireland for the first time. ${ }^{23}$ As shown in Figure 1.2, in $2015,3,444$ such permits were issued in Ireland, representing 9 per cent of the 38,433 first permits issued. First residence permits issued for family-related reasons represented the smallest category of permits issued, coming after education, employment and other. As mentioned in Section 1.3 this contrasts with the situation in the EU as a whole where permits issued for family-related reasons formed the largest category, accounting for 29 per cent of total new permits issued.

22 Valid residence permit means any authorisation valid for at least three months issued by the authorities of a Member State allowing a third-country national to stay legally on its territory (See Figure 1.5). Eurostat [migr_resfas]. 
Statistical data on applications made, granted and refused are available only for applications made under Section 18 of the Refugee Act 1996. In this section we present data on the number of individual family members who are the subjects of family reunification applications (henceforth family members), rather than on the number of applications by sponsor (see Annex I for data on applications by sponsor). Table 1.1 shows that the number of family members has decreased by 24 per cent between 2011 and 2016. The number decreased annually between 2011 and 2014 and then doubled between 2014 (353) and 2015 (713), likely due to the crisis in Syria and the Syrian Humanitarian Admission Programme ${ }^{24}$ (see Section 3.6 for more information). Provisional data for 2016 show a year-on-year increase in family members applied for (756 individual family members, endNovember 2016).

TABLE 1.1

FAMILY REUNIFICATION APPLICATIONS, GRANTS AND REFUSALS (DATA REFER TO FAMILY MEMBERS OF BENEFICIARIES OF INTERNATIONAL PROTECTION WHO ARE THE SUBJECTS OF FAMILY REUNIFICATION APPLICATIONS) 2011-2016

\begin{tabular}{|l|c|c|c|c|c|c|}
\hline & 2011 & 2012 & 2013 & 2014 & 2015 & $2016 *$ \\
\hline Family members applied for & 990 & 732 & 704 & 353 & 713 & 756 \\
\hline Family members granted & 547 & 389 & 207 & 229 & 328 & 406 \\
\hline Family members refused & 195 & 300 & 395 & 83 & 295 & 277 \\
\hline
\end{tabular}

Source: $\quad$ Family Reunification Unit, Irish Naturalisation and Immigration Service. See Annex I.

Note: $\quad * 2016$ data to end-November 2016. Grants and refusals may relate to different years than the application data.

Data on non-protection related family reunification are limited. Data on all permits $^{25}$ issued to non-EEA nationals for family reasons are published on Eurostat, but no disaggregation by sponsor type is available. However, based on the relative size of the populations that sponsors could potentially be drawn from, we can assume that the group of non-EEA family members of nonbeneficiaries is larger than the group of family members of beneficiaries of international protection: see Figure 1.5.

24 The Syrian Humanitarian Admission Programme was a family-based private sponsorship scheme which allowed Irish citizens of Syrian birth and Syrian nationals lawfully resident in Ireland to apply to bring family members in Syria or displaced from Syria in surrounding countries, to Ireland. 
FIGURE 1.5 NON-EEA RESIDENCE PERMITS VALID IN IRELAND IN 2015: BENEFICIARIES OF INTERNATIONAL PROTECTION AND OTHER ALL OTHER PERMIT HOLDERS

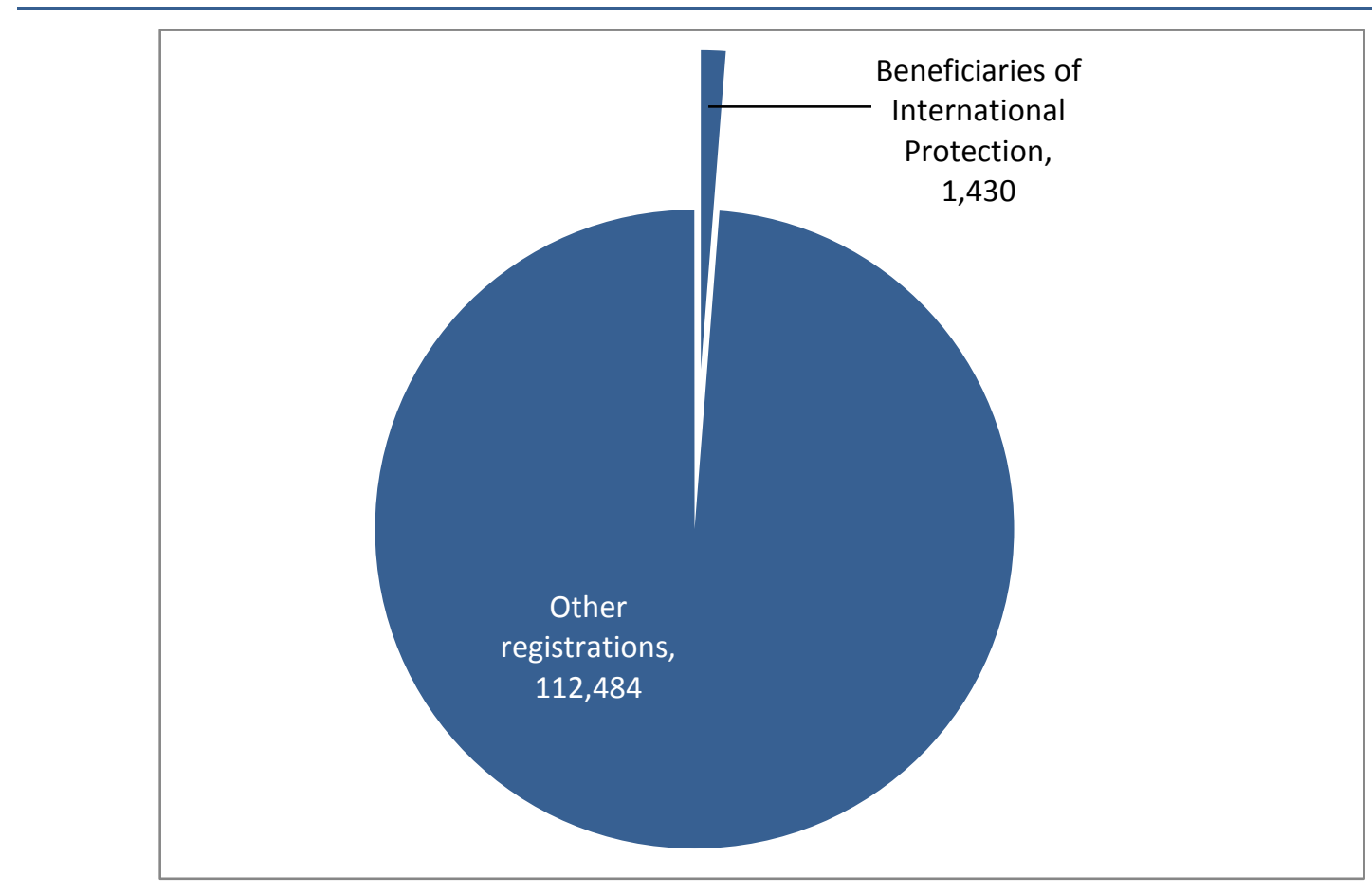

Source: Eurostat [migr_resvalid].

Data on visas are available for family members who are visarequired. ${ }^{26}$ Applications for visas for family reasons accounted for 12 per cent $(14,800)$ of the total 124,225 Irish visa applications in 2016, and 9 per cent $(54,310)$ of the total 609,216 applications between 2011 and 2016 (see Annex II). Visa applications granted for family reasons accounted for 7 per cent $(7,538)$ of the total 104,572 Irish visas granted in 2016 , and 7 per cent $(35,310)$ of the total 532,816 visas granted between 2011 and 2016.

Figure 1.6 shows that family members of non-EEA national sponsors accounted for 45 per cent $(24,521)$ of the total 54,310 visa applications 'for family reasons' made between 2011 and 2016 (37 per cent $(5,407$ ) of the total 14,800 applications in 2016). Visa applications made for family reasons increased annually between 2011 and 2015 but decreased by 9 per cent year-on-year $(16,287$ in 2015 and 14,800 in 2016). However applications in respect of family members of non-EEA national sponsors increased annually between 2011 and 2016 (with the exception of a small decrease between 2013 and 2014), increasing by 26 per cent year-on-year (4,306 in 2015 to 5,407 in 2016). 


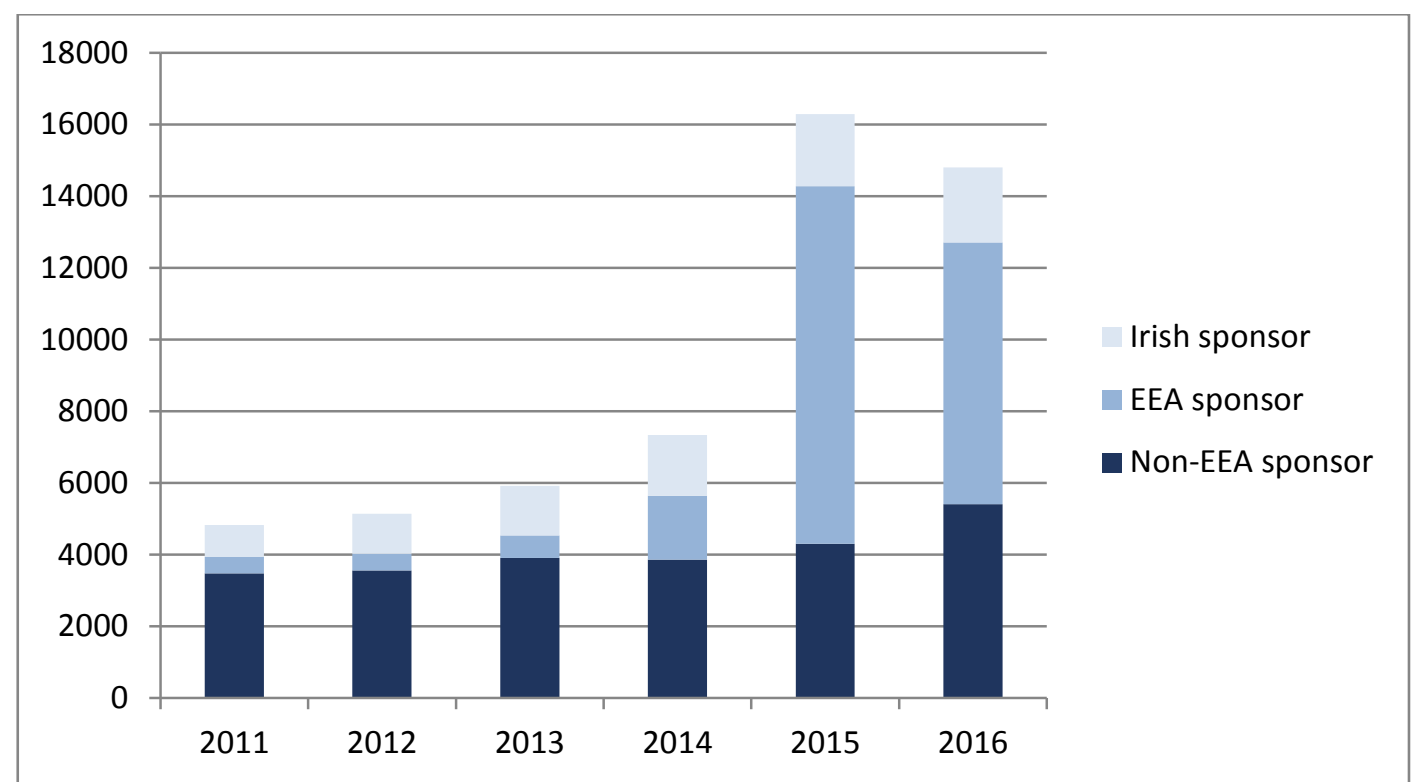

Visa Section, Irish Naturalisation and Immigration Service, 2017. See Annex II.

Figure 1.7 shows grants of visa applications in the period 2011-2016. Non-EEA national family members of non-EEA sponsors accounted for 60 per cent $(21,087)$ of the total 35,310 grants made between 2011 and 2016 (62 per cent $(4,658)$ of the total 7,538 applications in 2016). The total number of visa applications granted for family reasons increased annually between 2011 and 2015. The number of applications granted decreased by 13 per cent from 8,627 in 2015 to 7,538 in 2016. However visa applications granted for non-EEA family members of non-EEA sponsors increased annually between 2011 and 2016 (with the exception of a small decrease between 2013 and 2014), increasing by 58 per cent (from 2,955 in 2011 to 4,658 in 2016). ${ }^{27}$ 
FIGURE 1.7 VISA APPLICATIONS FOR FAMILY REASONS GRANTED IN IRELAND, 2011-2016

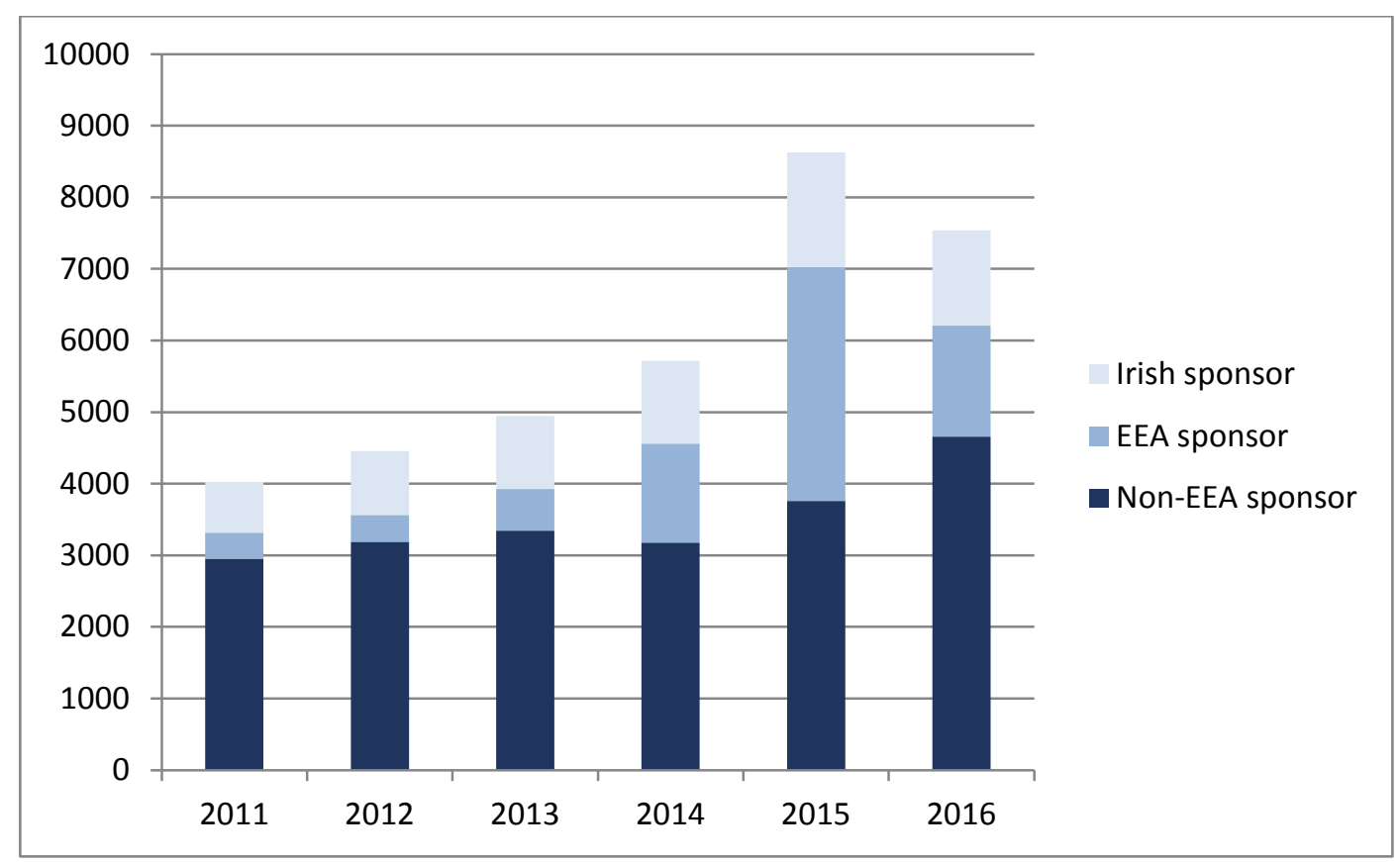

Source: Visa Section, Irish Naturalisation and Immigration Service, 2017. See Annex II.

Some 27 Syrians were refused visas for family reasons in the period January 2016 - 15 February 2017. In the same period, 18 Iraqis, eight Afghans, five Turkish, four Jordanian, three Lebanese and three Yemeni were refused visas for family reasons. ${ }^{28}$ In response to the publication of these figures, Nasc, the Irish Immigrant Support Centre (Nasc) expressed concern over visa refusals (see Table A2.3) that they argue are likely to affect elderly parents, women and children seeking to join family in Ireland. ${ }^{29}$

The top five nationalities of persons with a non-EEA sponsor granted visas for family reasons in 2016 were Indian, Saudi Arabian, Pakistani, Chinese and Egyptian (See Figure 1.8). refusals in respect of applicants applying from Syria, Iraq, Afghanistan, Lebanon, Jordan, Turkey and Yemen to join family members in Ireland. 
FIGURE 1.8 NATIONALITIES OF PERSONS GRANTED VISAS FOR FAMILY REASONS, 2016 (NON-EEA SPONSORS)

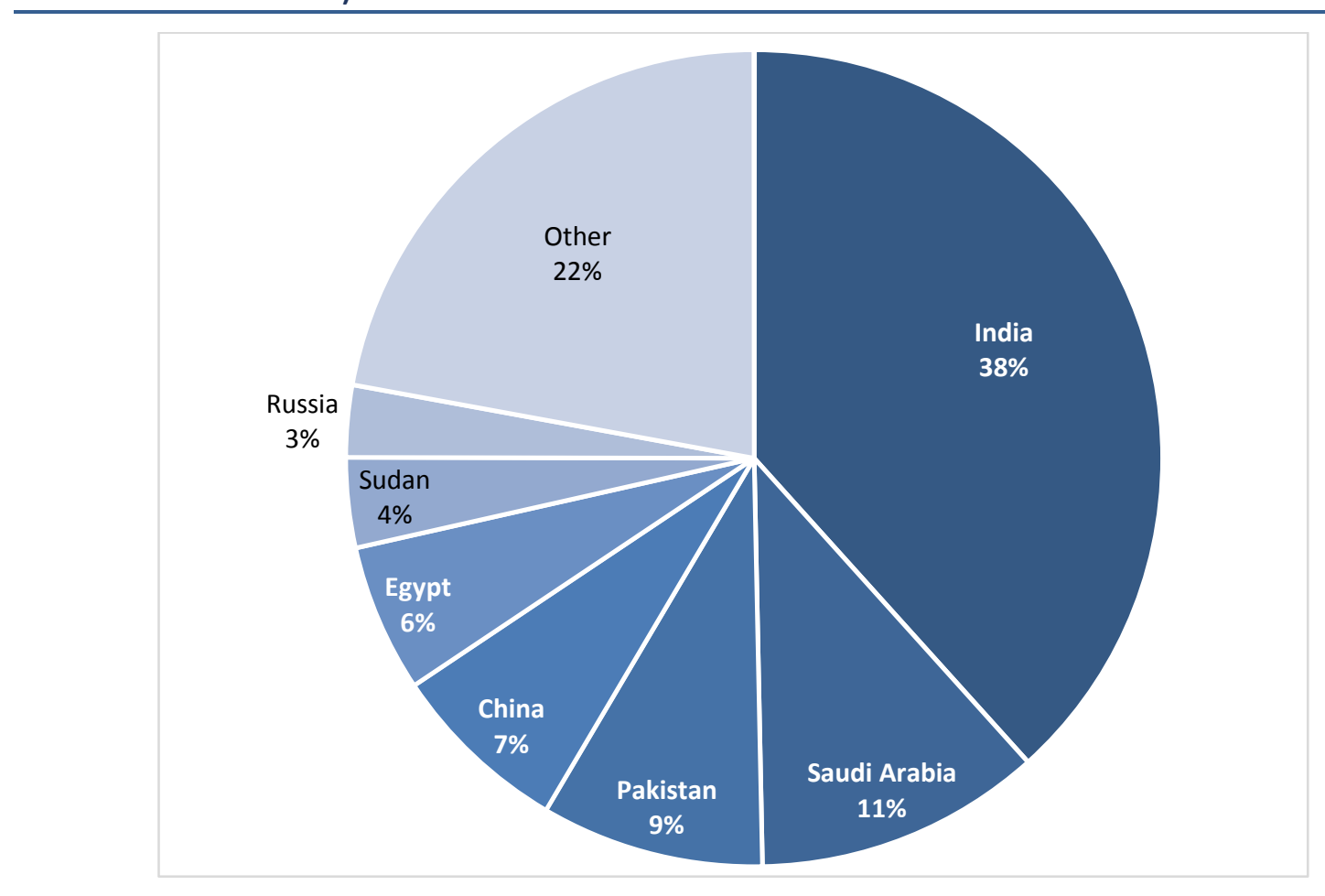

Source: Visa Section, Irish Naturalisation and Immigration Service, 2017. See Annex III.

\subsection{METHODOLOGY}

The study collates data and information on national and EU policy, practice and legislation on non-EEA family reunification. Its purpose is to provide an evidence base for national and EU policymakers, researchers, practitioners working with non-EEA nationals including beneficiaries of international protection, as well as the general public. In Ireland information on family reunification is available in the 2016 Policy Document on Non-EEA Family Reunification (INIS, 2016a). However the academic and NGO literature in this area remains sparse. The majority of the literature in Ireland pre-dates the publication of the Policy Document and the changes brought in through case law (see Section 4) and legislation (see Sections 2 to 4). This is the first comprehensive study on family reunification in Ireland since 2012 (Immigrant Council of Ireland, 2012) which outlines in detail the practice with input from a variety of stakeholders (see below). Furthermore this study takes account of the recent commencement of the International Protection Act 2015, which introduced significant changes to family reunification law for beneficiaries of international protection.

The scope of this study is limited to family reunification in the case of legally resident non-EEA nationals, including beneficiaries of international protection. Family reunification concerning Irish, EU and EEA nationals is excluded from this study. The temporal scope of analysis is January 2011 - December 2016. 
Desk research was undertaken at the outset of the study, including a review of existing academic and policy-based literature. The Policy Document on Non-EEA Family Reunification (INIS, 2016a) was a key source of information. A large amount of information was obtained from government publications and websites, in particular from INIS and the International Protection Office (IPO). National data on visa and on applications made by beneficiaries of international protection were obtained through INIS. Some national and EU residence permit data were obtained through Eurostat.

Interviews were undertaken with officials from INIS, UNHCR Ireland, Immigrant Council of Ireland (ICI), Nasc and Crosscare Migrant Project. Outstanding information gaps were filled with comments from INIS, as well as from the aforementioned NGOs. The report was internally and externally reviewed.

The information used to produce this report was gathered according to commonly agreed European Migration Network (EMN) specifications developed to facilitate comparability across countries. The $\mathrm{EMN}^{30}$ is tasked with producing studies on topics of relevance to policymakers at national and EU levels, in order to meet long- and short-term information needs. Topics may be proposed for indepth strategic studies with long-term relevance, or for shorter studies, responding to immediate information needs. Each EMN National Contact Point produces a national report, and a comparative, EU-level synthesis report is then produced, which brings together the main findings from the national reports and places them within an EU perspective. ${ }^{31}$

The common template for this study follows the provisions contained within Council Directive 2003/86/EC on the right to family reunification. Although this report does not intend to analyse to what extent Irish family reunification law and policy takes account of or reflects the provisions in the Directive, the Directive is used as a framework through which Irish policy and law is discussed. Most sections in this report therefore refer to the relevant provisions in the Directive. 


\section{SECTION 2}

\section{Applying for family reunification}

Section 2 describes the application process for family reunification in Ireland.

\subsection{INTRODUCTION: GENERAL OVERVIEW OF APPLICATION PROCEDURE}

The subject of the application is the family member, but the process is seen as a joint undertaking between the sponsor and the family member seeking residence in Ireland (INIS, 2016a).

\subsection{VISA REQUIRED NATIONALS}

Applications made by non-EEA nationals located outside the State generally begin with an online visa application (INIS, 2016a). Visa applications are governed by administrative procedure. Not all nationalities are visa-required. ${ }^{32}$

Critics have pointed to challenges that may be posed by the online application process, including lack of access to a computer ${ }^{33}$ and low computer literacy. ${ }^{34}$ INIS noted that such barriers are not unique to family reunification applications. ${ }^{35}$ $\mathrm{NGOs}^{36}$ have observed that applications are sometimes started in Ireland by the sponsor, the summary page is then sent abroad to the family member for his or her signature. Delays can result due to reliance on postal services and problems coordinating between family members. ${ }^{37}$

The signed summary sheet of the visa application must then be submitted to the relevant Irish Embassy or Consulate in the country where the applicant is residing (or to the responsible Embassy in another country if none exists in the country of residence). NGOs observed that family members may not be able to access embassies, in particular in places where large regions are serviced by one embassy, though this is not a challenge specific to family reunification visa applications. ${ }^{38}$ Interviewees also identified difficulties getting documents out of 
the country; they might be stopped by customs en route to Ireland, or between the service provider ${ }^{39}$ operating in a country without an Irish embassy and the embassy in another country. This can be time consuming and expensive; the online visa application may 'time out' in the meantime (again not a problem specific to family reunification applications). ${ }^{40}$

A non-refundable fee of $€ 60$ (single entry visa) or $€ 100$ (multiple-entry visa) is required at the time of application. Nasc identified paying the fee as a challenge as it must be paid by bank draft in Ireland or abroad. In some cases, when the embassy is located in another country, the fee may be in a different currency. ${ }^{41}$ This is a challenge that may exist across all immigration channels.

The progress of visa applications can be checked online either through the INIS website or the relevant Visa Office/Embassy or Consulate. If the visa application is refused, family members may appeal in writing within two months of the decision by way of an internal review process to the Visa Appeals Office, INIS. ${ }^{42}$ Appeals are also processed by INIS overseas Visa Offices. ${ }^{43}$ There is no mandatory processing time for visa appeals (Immigrant Council of Ireland, 2012).

If the family member is not satisfied with the outcome of the appeal, he or she may be able to seek a judicial review of the decision. Family members may also make a subsequent application. ${ }^{44}$ If the application is rejected on the basis of fraud, the family member may not apply for another visa for five years. ${ }^{45}$

The granting of a visa entitles the holder to present at the border; it does not guarantee entry to Ireland. Refusal of permission to land or enter Ireland may arise where the person requires a visa but is not in possession of one, or whose entry may pose a threat to national security or public policy (see Section 3). The immigration officer must provide the reasons for refusal in writing, but the decision is not open to appeal. Centres (VACs) where applications for Irish visas are made (Quinn, 2011). Interview with Nasc, December 2016.

41 Ibid. Applicants have 28 days to submit documents to the Visa Office once the online application is made. The application may time out before the above issues are resolved, but this is not a challenge specific to family reunification applications.

42 INIS, 'Visa Appeals' www.inis.gov.ie; www.inis.gov.ie/en/INIS/Pages/Visa\%20Appeals.

43 Interview with INIS, December 2016. There are seven overseas visa offices in; China, India, Nigeria, Russia, Turkey, United Arab Emirates and the United Kingdom.

44 Although $\mathrm{ICl}$ note that applicants may be reluctant to do this after having already been refused once. Interview with Immigration Council of Ireland, November 2016.

45 Interview with Immigration Council of Ireland, November 2016. 
Once in the country, all third-country nationals must present to an immigration officer on arrival and seek permission to enter, pursuant to Section 4 of the Immigration Act 2004, within 90 days of arrival. A certificate of registration is issued which states the type of permission that has been granted. The registrant must pay a fee of $€ 300$. This fee is waived in the case of family members of beneficiaries of international protection.

\subsection{NON-VISA REQUIRED NATIONALS}

Non-visa required nationals must travel and be admitted to the State and subsequently make a family reunification application from within the State. Applications from non-visa required nationals are made by letter to INIS with relevant documentation (see Sections 3 and 4). Application forms are provided for family members of Critical Skills Employment Permit Holders and non-EEA national migrant workers. Critics have argued that having to undertake the application process once already in the country creates a situation of uncertainty (Immigrant Council of Ireland, 2012).

\subsection{FAMILY FORMATION/CHANGE OF FAMILY CIRCUMSTANCES}

If a person becomes a family member while residing in Ireland legally, the person can seek a 'change of status'. In such a case the individual(s) do not follow a formal application process - the sponsor presents along with their spouse/family member and documentation confirming their relationship to the Garda National Immigration Bureau (GNIB) to request a change of status. If this is not granted, the person may then apply to INIS (Gotzelmann, 2016).

There is no automatic right of residence independent of the sponsor except where the family member is a victim of domestic violence. Evidence of domestic violence is required. ${ }^{46}$ No application fee applies in change of status applications for reasons of domestic violence.

It may be possible to apply for a change of status where the family circumstances change. For example, an application for a change of status can be made where a refugee sponsor passes away or beneficiary children reach 18 years of age and establish their own family. If the sponsor's refugee status is revoked the family member may apply for humanitarian permission to remain in the State. ${ }^{47}$ 


\subsection{BENEFICIARIES OF INTERNATIONAL PROTECTION}

Sponsors who are beneficiaries of international protection may apply in writing to the Family Reunification section of INIS, providing basic information such as the sponsor's name, Person ID number, address and details of the family member(s). Prior to the commencement of the Act of 2015, beneficiaries of international protection wrote to the Office of the Refugee Applications Commission (ORAC) (now the International Protection Office) to apply for family reunification. ORAC was responsible for processing applications for family reunification except in the case of dependent family members. INIS dealt with applications where the subject of the application was a dependent family member.

Pursuant to Section 56(8) of the Act of 2015, applications must now be made within 12 months, to run from the date on which the sponsor was given a declaration of international protection. This is a new provision and time limits did not apply under the Refugee Act 1996 (see Section 1.4). Once preliminary information is received by INIS, a questionnaire is sent to sponsors. The questionnaire must be returned along with the documents listed in Table 4.1, Section 4. The application is considered and the sponsor may be contacted for further information during this process. The sponsors will receive a written decision. The decision cannot be appealed. ${ }^{48}$ Negative decisions may be judicially reviewed by application to the High Court. Family members who receive a positive decision must then apply for a visa, if required. ${ }^{49}$ The cost of the visa application per individual is $€ 60$ for a single entry visa and $€ 100$ for a multi-entry visa. Some family members are exempt from the application fee, for example family members of Programme Refugees. ${ }^{50}$

Family reunification in the context of international protection differs from the larger non-EEA national cohort in two ways. Firstly, family reunification is provided for in law. In other words there is a clear legal entitlement to family reunification for nuclear family members. Secondly, no financial requirements/ thresholds are imposed upon the sponsor.

Programme Refugees (refugees resettled from a third country under the UNHCRled resettlement programme) may also apply for family reunification (Arnold and Quinn, 2016). They often apply for reunification with family members almost immediately upon arrival in Ireland, in contrast to spontaneous beneficiaries of international protection who must wait for a decision on their protection

INIS, 'The International Protection Act 2015 - Family Reunification Information', www.inis.gov.ie.

If from a visa required country.

Nationals exempt from visa fees include: Bosnia, Cote d'Ivoire, Ecuador, Indonesia, Jamaica, Kosovo, Kyrgyzstan, Montenegro, Morocco, Peru, Republic of Macedonia, Serbia, Sri Lanka, Tunisia, Uganda and Zambia. Spouses and children of Irish nationals are also among those exempt from visa fees. INIS, 'Fees', www.inis.gov.ie. 
application prior to submitting family reunification applications. ${ }^{51}$ In addition, all Programme Refugees arrive in Ireland with identity documents and they have access to general support and information in the reception centres (during the orientation programme). For these reasons, applications from Programme Refugees may be more straightforward to process. ${ }^{52}$

\subsection{TRAVEL TO IRELAND}

Once family reunification is granted, family members must make arrangements to travel to Ireland. UNHCR observed that this includes the arrangement of travel documents if the family members do not have national passports and cannot obtain exit permissions for them, in particular in cases where they are residing in a country other than their country of nationality; and flight arrangements. ${ }^{53}$ Pursuant to Section 56(5) of the Act of 2015, any permission to enter and reside in the State which has been granted on foot of the application must be taken up by the date specified by the Minister when granting it, otherwise the permission shall cease to be in force.

A number of challenges to joining family in Ireland were identified in this study, including cost (Gotzelmann, 2016). ${ }^{54}$ In order to mitigate the challenges associated with travelling to join family in Ireland, UNHCR and the Irish Red Cross have been operating a limited Travel Assistance Scheme for a number of years, generally on a 50/50 cost split basis where funding is available, to assist beneficiaries of international protection who demonstrate that they lack sufficient resources to cover the costs of travel for family members. Sponsors may be eligible if in receipt of social welfare payments or on the minimum wage. IOM is a partner to UNHCR on this scheme and manages the often complex logistics in conjunction with UNHCR and the Irish Red Cross. ${ }^{55}$ Table 2.1 shows that the number of persons assisted to travel to Ireland under the Travel Assistance Scheme has increased dramatically in 2015 and $2016 .{ }^{56}$ UNHCR noted that, while funding for this scheme has increased over recent years, a significant growth in requests for financial assistance in 2016 and 2017 to date ${ }^{57}$ means that it may not be possible to meet the demand for support in 2017. ${ }^{58}$ UNHCR further noted that a sustainable funding mechanism, beyond that provided by UNHCR and the Irish Red Cross, is required in order to ensure that persons granted family reunification permissions have effective access to that right. ${ }^{59}$

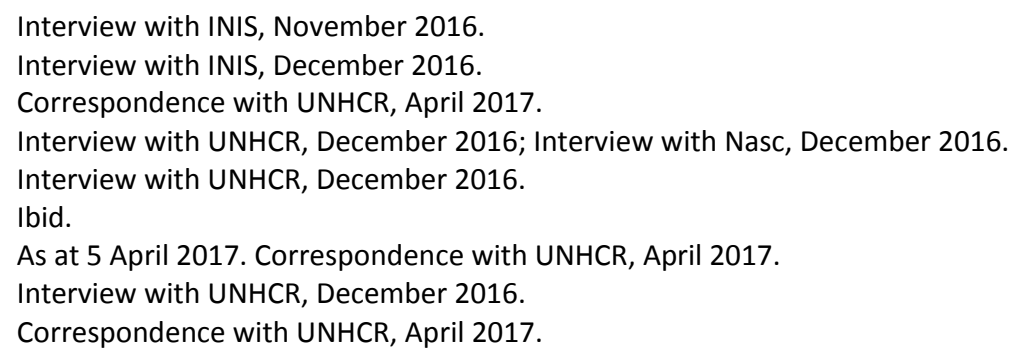


TABLE 2.1 PERSONS ASSISTED TO TRAVEL TO IRELAND UNDER THE TRAVEL ASSISTANCE SCHEME

\begin{tabular}{|c|c|c|c|c|c|c|}
\hline Year & 2011 & 2012 & 2013 & 2014 & 2015 & 2016 \\
\hline Cases & 12 & 7 & 2 & 5 & 17 & 38 \\
\hline Persons & 42 & 32 & $<10$ & 11 & 43 & 105 \\
\hline
\end{tabular}

Source: $\quad$ UNHCR Ireland, 2017.

Other challenges faced by family members included travelling on a travel document from or through a country that does not recognise the document. ${ }^{60}$ UNHCR Ireland observed that travel documents are only issued by INIS in very limited circumstances to enable family members with permission to travel to Ireland. ${ }^{61}$ In addition problems may present during the visa application process, including where family reunification for beneficiaries of international protection has already been granted (see Section 2.2).

\subsection{LENGTH OF TIME}

Applications for family reunification from non-EEA nationals, including beneficiaries of international protection, are dealt with by INIS in chronological order but some may be processed more quickly than others. According to INIS if the sponsor is an Irish citizen or a sponsor who is entitled to apply for immediate family reunification, applications should be dealt with within six months of receipt of all required documentation. ${ }^{62}$ All other applications should be dealt with within 12 months of receipt of all required documentation. ${ }^{63}$ Particularly urgent cases may be expedited, for example applications from Syrians, but INIS noted that the expedited list can be as long as the ordinary list. ${ }^{64}$

The literature (Gotzelmann, 2016) confirmed that during 2016 the average processing time for a family reunification application was 12 months, which suggests that all applications are being resolved within the 12-month limit set by INIS. This process may be extended where additional documentation is required or where issues arise in relation to submitted documentation (Gotzelmann, 2016). ${ }^{65}$ In the context of international protection INIS noted that the processing

60 Turkey does not recognise International Committee of the Red Cross travel documents. Nasc identified this as a challenge for Syrians living there and planning to travel to Ireland. Interview with Nasc, December 2016.

Correspondence with UNHCR, April 2017.

INIS, 'Join Family' www.inis.gov.ie.

Interview with INIS, November 2016.

Interview with INIS, December 2016.

Interview with INIS, November 2016. 
time for applications was 12 to 13 months. ${ }^{66}$ Critics and practitioners identify processing time as a key challenge. ${ }^{67}$

\subsection{CHALLENGES TO ACCESSING THE PROCESS OF FAMILY REUNIFICATION}

Immigrant Council of Ireland (2012) identified the lack of a legal entitlement to family reunification as a barrier for family members whose sponsors are not beneficiaries of international protection. In addition and prior to the publication of the 2013 Policy Document, critics argued that there was a lack of transparency and clarity around application and decision-making processes. Research highlighted access to information and customer service assistance as challenges (Immigrant Council of Ireland, 2012). More information and guidance is now available as a result of the Policy Document, its 2016 revision and the guidelines on family reunification for beneficiaries of international protection, as well as developments arising from case law. Critics nevertheless continue to argue that there is a lack of clarity and insufficient guidelines (Gotzelmann, 2016), in particular for individuals whose first language is not English. ${ }^{68}$

Critics also observed that applications are dealt with by a number of different divisions within INIS, which may create an obstacle for family members and sponsors who may find it difficult to access clear information about the procedure and their rights in respect of family reunification. ${ }^{69}$ INIS noted that there are a number of different units processing applications based on their particular expertise. ${ }^{70}$

The research points to a lack of tailored legal services dealing with family reunification applications. There is a dedicated unit of the Legal Aid Board which provides legal services to persons seeking asylum, but the unit does not ordinarily provide legal service in respect of refugee family reunification applications (Immigrant Council of Ireland, 2012).

INIS noted that family reunification cases are among the most labour intensive in the immigration caseload (INIS, 2016a). Stakeholders interviewed for the present study also observed that family reunification applications can be onerous for some people and that legal services may be required; ${ }^{71}$ the research also

Ibid.

Interview with Immigrant Council of Ireland, November 2016; Interview with Nasc, December 2016.

Interview with Immigrant Council of Ireland, November 2016.

Ibid. See also: Immigrant Council of Ireland (2012). Family Reunification a barrier or facilitator of integration? Dublin: Immigrant Council of Ireland.

Interview with INIS, December 2016.

Interview with Immigrant Council of Ireland, November 2016; Interview with Nasc, December 2016. 
supports this view (Immigrant Council of Ireland, 2012). Critics have described the process as lengthy, 'not applicant friendly' and 'prohibitively costly' (Gotzelmann, 2016). Legal services are particularly needed at the administrative review stage and/or judicial review (Immigrant Council of Ireland, 2012).

A number of NGOs provide assistance with family reunification applications, ${ }^{72}$ including Nasc who reported an increase in persons presenting looking for information on family reunification in 2016. ${ }^{73}$ UNHCR may also provide support and assistance to beneficiaries of international protection in verifying that they or a family member is/was registered with UNHCR in another country. ${ }^{74}$ Organisations also reported working together to assist sponsors and their families, for example a staff member from UNHCR Ireland recently provided interpretation services for a few days to assist Nasc in their efforts to process a backlog of requests for support with family reunification applications. ${ }^{75}$ Nasc also reported working with both UNHCR and the Irish Red Cross on obtaining necessary travel documents for service users. ${ }^{76}$ 


\section{SECTION 3}

\section{Eligibility for family reunification}

Section 3 provides information on eligible sponsors, eligible family members and the necessary requirements to make an application.

\subsection{INTRODUCTION}

Any legally resident non-EEA national is potentially free in their own right to seek to be joined by family members (INIS, 2016a). The Policy Document provides information on eligible sponsors and family members. The International Protection Act, 2015 defines which family members are eligible to join beneficiaries of international protection. Family reunification operates on the basis of ministerial discretion in all cases except those concerning nuclear family members of beneficiaries of international protection (see Section 3.5).

\subsection{ELIGIBLE NON-EEA SPONSORS}

While all persons legally resident in Ireland may make an application for family reunification, the following categories of non-EEA eligible sponsors are specifically referred to in the INIS (2016) Policy Document:

- Lawfully resident foreign nationals with Stamp 4 permission;

- Employment permit holders;

- Beneficiaries of international protection (see Section 3.5);

- Lawfully resident foreign nationals with Stamp 5 permission (denoting that their residence is without condition as to time);

- Researchers under a Hosting Agreement;

- PhD students studying for a doctorate accredited in Ireland; and

- Ministers of religion with Stamp 3 permission.

The above named categories of non-EEA sponsors may apply to be joined by nuclear family members and other family members (see below).

Not all sponsors are immediately eligible to apply for family reunification however. Those who are immediately eligible, or Category A sponsors, are:

- Critical skills employment permit holders;

- Investors; 
- Entrepreneurs;

- Business permission holders;

- Researchers;

- INIS approved scholarship programme students;

- Intra-Company Transfers;

- PhD students (subject to conditions including no recourse to social welfare);

- Full-time non-locum doctors in employment; and

- Beneficiaries of international protection.

The above-named sponsors are assumed to meet income requirements as their residence requires certain thresholds to be met, except beneficiaries of international protection (see Section 3.5). For example, in accordance with Directive 2005/71/EC, scientific researchers must be provided with sufficient resources to meet their needs without accessing public funds, the same conditions apply in the case of admission of family members. ${ }^{77}$ Non-immediate family members can be sponsored after a period of two years (INIS, 2016a).

Persons with non-critical skills employment permits, all Stamp 4 holders not covered by more favourable arrangements (e.g. beneficiaries of international protection) and Ministers of Religion, ${ }^{78}$ or Category $\mathrm{B}$ sponsors, may be eligible for family reunification after 12 months residence in Ireland (INIS, 2016a). These sponsors may be granted family reunification at the discretion of the Minister when the sponsor has been in employment for twelve months prior to the date of application, is in full-time employment at the time of application and has an income above the threshold that would qualify the family for a payment under the Family Income Supplement (FIS) Scheme (See Section 3.4.1, Table 3.1). ${ }^{79}$ Nonimmediate family members can be sponsored after a period of five years (INIS, 2016a).

\subsection{ELIGIBLE FAMILY MEMBERS}

In general eligible family members include spouses and children. This is consistent with the Directive. There is no distinction in terms of eligibility between family reunification and family formation in Ireland concerning non-EEA nationals (INIS, 2016a), except in the case of beneficiaries of international protection. 
In the case of beneficiaries of international protection, marriages and partnerships, including same sex marriages and partnerships, must be established prior to the date of application for international protection in Ireland pursuant to Sections 56 and 57 of the International Protection Act, 2015. This is consistent with Article 9.2 of the Directive. ${ }^{80}$ Critics have highlighted that persons who apply for international protection on the basis of sexual orientation or gender identity are unlikely to have been able to register partnerships prior to applying for protection, due to laws or severe discrimination in the country origin (Finn, 2017; Spijkerboer, 2013).

Proxy marriages ${ }^{81}$ may also be recognised under Irish law, but they must be legal marriages registered in the country of origin. Applications for more than one spouse (i.e. in the context of polygamous marriages) are not facilitated (INIS 2016a) (see Section 3.8).

The INIS Policy Document (2016a) also outlines reunification with other family members. The document explicitly mentions parents, including elderly dependent parents (see Section 3.4.2), adult children and de facto partners. Adult children of the sponsor may be eligible for family reunification up to the age of 23 where they are in full-time education and dependent on their parents for support. Adult children who are dependent on the adult sponsor due to a serious medical condition may also be eligible. ${ }^{82}$ Persons in de facto relationships, which are akin to marriage, for a minimum period of two years prior to application, are eligible for reunification (see Section 4, Table 4.1).

\subsection{REQUIREMENTS BY TYPE OF NON-EEA SPONSOR}

\subsubsection{Financial criteria}

In general no formal requirements must be met by the applicant as regards housing, health insurance or integration. Health insurance is not a requirement for eligibility during the application process itself, but it may be requested at the visa application stage. ${ }^{83}$ Housing does not form part of the application process itself, but Nasc commented that accommodation may arise in respect of an assessment as to whether or not a cost would be incurred to the State. ${ }^{84}$

'Member States may confine the application of this Chapter to refugees whose family relationships predate their entry'.

81 A proxy marriage is a marriage where one or both persons being united are not physically present. See: Hamza $v$. Minister for Justice, Equality and Law Reform [2013] IESC 9.

82 In cases where independent living in the home country would be impossible. Nasc, 'Family Reunification Factsheet', www.nascireland.org/wp-content/uploads/2013/09/Family-Reunification-Factsheet-2.pdf.

INIS, 'Join Family' www.inis.gov.ie.

Interview with Nasc, November 2016. 
Language competency and Irish culture tests have been proposed in the context of immigration more generally (INIS, 2016a), but to date nothing of this nature has been introduced.

Income requirements are applied, however, and these vary depending on the residence permission of the sponsor. It is the responsibility of all sponsors to satisfy INIS that the level of income or financial resources is sufficient for sponsorship (INIS, 2016a). ${ }^{85}$ Detailed financial statements, including bank statements ${ }^{86}$ from sponsors and family members, must be submitted to show that they have sufficient funds to support dependent family members (INIS, 2016a). The minimum income level is $€ 30,000$ (INIS, 2016a). The Policy Document provides guidance based on income levels applied to test eligibility for the Family Income Supplement (FIS) (the FIS is a weekly tax-free payment available to support low-earning employees with children). ${ }^{87}$ Sponsors are normally required to earn more than the income limits listed in Figure 1.6. The FIS information is provided for guidance purposes and represents a minimum income threshold (INIS, 2016). Declared and verified savings of the applicant or sponsor may be taken into account. INIS noted that applications from persons in full-time employment have a greater likelihood of success (INIS, 2016a).

\section{TABLE 3.1 FAMILY INCOME SUPPLEMENT WEEKLY INCOME LIMITS 2016/2017}

\begin{tabular}{|l|r|}
\hline Number of dependent children & Net family income less than \\
\hline 1 child & $€ 511$ \\
\hline 2 children & $€ 612$ \\
\hline 3 children & $€ 713$ \\
\hline 5 children & children \\
\hline 6 children & $€ 934$ \\
\hline 7 children & $€ 1,076$ \\
\hline 8 children & $€ 1,212$ \\
\hline
\end{tabular}

Source: Department of Social Protection.

Evidence of the finances of the family member(s) and sponsor must be provided in the form of a detailed statement of bank accounts of both parties covering a

85 INIS may consult directly with the Revenue Commissioners as appropriate (INIS, 2016).

86 Detailed bank accounts for both parties covering a six-month period immediately prior to the application must be provided. Where the sponsor lives in Ireland and for persons eligible after 12 months, the sponsor must provide evidence that they meet the minimum level of earnings required. P60s for the three years immediately prior to the date of application and three recent consecutive pay slips (if self-employed, Notices of Assessment of income from self-employment for the three most recent years and evidence of earnings in the period since the most recent tax return was filed) are required. For persons who are eligible to sponsor immediately, they must provide evidence of projected earnings (e.g. copy of contract of employment). INIS, 'Join Family' www.inis.gov.ie. 
six-month period immediately prior to the application. The sponsor must provide evidence that they meet the minimum level of earnings required.

Persons who are eligible to sponsor immediately must provide evidence of projected earnings, such as a copy of their contract of employment. Persons who are eligible to sponsor after 12 months must provide evidence that they meet the minimum level of earning required. P60s for the previous two years (or previous one year in the case of an employment permit holder who has only been in Ireland for one year) must be submitted (if self-employed, Notices of Assessment of income from self-employment must be submitted, as appropriate); three consecutive pay slips; in the case of an employment permit holder, a copy of their contract of employment of at least one year from the proposed date of entry; and evidence of annual salary. ${ }^{88}$

The INIS Policy Document provides for the exercise of discretion on the part of the decision-maker when balancing competing elements of the application:

Economic considerations are thus a very necessary part of family reunification policy. While it is not proposed that family reunification determinations should become purely financial assessments the State cannot be regarded as having an obligation to subsidise the family concerned and the sponsor must be seen to fulfil their responsibility to provide for his/her family members if they are to be permitted to come to Ireland (INIS 2016a).

Applicants may request that income requirements are waived on humanitarian grounds, for example in the case of a family member with a disability or in the case of victims of trafficking (INIS, 2016a). ${ }^{89}$ Nasc observed that the fact that disability allowance is considered as income is positive, noting that it ensures persons with a disability who are unable to work are not excluded from enjoying their right to family reunification. ${ }^{90} \mathrm{NGO}$ s have observed that having the income requirements waived is difficult ${ }^{91}$ and requires a great deal of advocacy including letters from (medical) social workers, public health nurses and other family supports. ${ }^{92}$

Gotzelmann (2016) wrote that it is unclear how the various 'factors are evaluated and weighed against each other when a decision is reached'. However NGO

INIS, 'Join family' www.inis.gov.ie.

Interview with Immigrant Council of Ireland, November 2016.

Interview with Nasc, December 2016.

Ibid.

Interview with Immigrant Council of Ireland, November 2016. 
interviewees reported that financial considerations were at the fore, ${ }^{93}$ the INIS Policy Document confirms this.

ICI (2012) called for increased transparency and a limit to Ministerial discretion, identifying a lack of uniformity in decision-making. Subsequent to the ICl study, however, INIS published the Policy Document, mentioned throughout (INIS, 2016a). ICI noted that while discretion can lead to inconsistencies in the determination of family reunification applications, it is applied favourably in some cases. $^{94}$

All of the above criteria, specifically financial requirements, are considered during the application phase, but they may also be assessed upon renewal of the residence permission annually. ${ }^{95}$ The registration process, to which all family reunification beneficiaries are subject, involves a decision to issue residence permission by an immigration officer. Nasc notes that discretion plays a significant role in this process and the documentation required may vary depending on the individual officer. ${ }^{96}$

Applications submitted pursuant to Sections 56 and 57 of the International Protection Act 2015 have an automatic right to family reunification and do not have to satisfy any financial or other conditions (see Section 3.5).

Income assessment in the case of Irish nationals is less onerous than in the case of non-EEA nationals. Nasc have observed an increase in persons waiting until they are naturalised Irish citizens to make applications because the process is more straightforward. ${ }^{97}$

\subsubsection{Elderly dependent parents}

The criteria are different for family reunification applications made in respect of elderly parents. Sponsors of an elderly dependent relative are required to have earned $€ 60,000$ after tax and deductions in Ireland in each of the three years preceding the application and $€ 75,000$ where two parents are involved. Sponsors are 'required to sign a legal undertaking to the effect that they will bear personal complete financial responsibility' and provide detailed information regarding the 
provision of accommodation. Elderly dependent parents are also required to have private medical insurance cover (INIS, 2016a). ${ }^{98}$

\subsection{BENEFICIARIES OF INTERNATIONAL PROTECTION}

Beneficiaries of international protection have an automatic right to family reunification with nuclear family members, pursuant to Sections 56 and 57 of the International Protection Act, 2015. As mentioned in Section 1, family reunification is only provided for in law for beneficiaries of international protection. According to the Act of 2015 only refugees and beneficiaries of subsidiary protection are eligible for family reunification. However INIS has confirmed that Programme Refugees are also eligible to apply utilising Sections 56 and $57 .{ }^{99}$ Section 56 (9) of the Act of 2015 defines family member, in relation to the sponsor, as:

(a) where the sponsor is married, his or her spouse (provided that the marriage is subsisting on the date the sponsor made an application for international protection in the State),

(b) where the sponsor is a civil partner, his or her civil partner (provided that the civil partnership is subsisting on the date the sponsor made an application for international protection in the State),

(c) where the sponsor is, on the date of the application under subsection (1) under the age of 18 years and is not married, his or her parents and their children who, on the date of the application under subsection (1), are under the age of 18 years and are not married, or

(d) a child of the sponsor who, on the date of the application under subsection (1), is under the age of 18 years and is not married.

While Ireland exercised its right not to participate in the Directive, INIS noted that Sections 56 and 57 of the Act of 2015 were drafted in line with the provisions of the Directive. ${ }^{100}$ The definition provided above is a close reflection of Article 4 of the Directive, with some exceptions. ${ }^{101}$ For example Article 4 stipulates that

\footnotetext{
'at or above the level of VHI D or equivalent'. Interview with INIS, November 2016.

Ibid.

Article 4.1 'The Member States shall authorise the entry and residence, pursuant to this Directive and subject to compliance with the conditions laid down in Chapter IV, as well as in Article 16, of the following family members: (a) the sponsor's spouse; (b) the minor children of the sponsor and of his/her spouse, including children adopted in accordance with a decision taken by the competent authority in the Member State concerned or a decision which is automatically enforceable due to international obligations of that Member State or must be recognised in accordance with international obligations; (c) the minor children including adopted children of the sponsor where the sponsor has custody and the children are dependent on him or her. Member States may authorise the reunification of children of whom custody is shared, provided the other party sharing custody has given his or her agreement; (d) the minor children including adopted children of the spouse where the spouse has custody and the children are dependent on him or her. Member States may authorise the reunification of children of whom custody is shared, provided the other party sharing custody has given his or her agreement. The minor children referred to in this Article must be below the age of majority set by the law of the Member State concerned and must not be married.
} 
adopted children are eligible for reunification. INIS confirmed that adopted children, and indeed any children where legal guardianship can be established, are eligible for family reunification even though they are not explicitly referred to in the legislation. ${ }^{102}$

The Directive also provides a broader definition of family for unaccompanied minors than the Act of 2015, requiring Member States to

authorise the entry and residence for the purposes of family reunification of his/her first-degree relatives in the direct ascending line without applying the conditions laid down in Article 4(2)(a). ${ }^{103}$

Article 10.3(b) of the Directive also provides that Member States may authorise the entry and residence for the purposes of family reunification of his/her legal guardian or any other member of the family, where the refugee has no relatives in the direct ascending line or such relatives cannot be traced.

Section 56(9)(d) of the Act of 2015 is therefore more limited in scope than the Directive in respect of unaccompanied minors.

\subsubsection{Dependent family members of beneficiaries of international protection}

The Act, which commenced 31 December 2016, replaced the Refugee Act 1996, as amended. Dependent family members were among those eligible for family reunification under the Refugee Act 1996 while the Act of 2015 limits family reunification to nuclear family members. Section 18(4) of the Refugee Act 1996 provided for 'dependent members of the family' of a refugee to be permitted to enter and reside in the State at the discretion of the Minister, namely:-

'any grandparent, parent, brother, sister, child, grandchild, ward or guardian of the refugee who is dependent on the refugee or is suffering from a mental or physical disability to such extent that it is not reasonable for him or her to maintain himself or herself fully'. ${ }^{104}$

INIS described the Refugee Act, 1996 as less restrictive than the Directive as it provided for reunification with dependent relatives at the discretion of the

'(a) first-degree relatives in the direct ascending line of the sponsor or his or her spouse, where they are dependent on them and do not enjoy proper family support in the country of origin'.

See also: European Communities (Eligibility for Protection) Regulations 2006, Regulation 16. 
Minister. ${ }^{105}$ However UNHCR expressed concern over the omission of dependent family members from the Act of 2015 and narrowing of the category of eligible family members to nuclear family only. ${ }^{106}$ Programme Refugees in Ireland are resettled as a family unit and thus utilised Section 18.4 to apply for family reunification with dependent family members. This avenue, however, is no longer available under the Act of 2015.

INIS described the changes in respect of family reunification as the biggest change to refugee law to come in under the new Act. ${ }^{107}$ INIS noted that the changes, namely the new 12-month time limit within which to apply and the narrower definition of family member, will speed up the process in part by reducing the number of applications received. ${ }^{108}$

It is important to note that beneficiaries may still apply for family reunification utilising the general administrative mechanisms available to non-EEA nationals, discussed throughout the current study (i.e. applications made within the scope of the Policy Document). ${ }^{109}$ Pursuant to Section 18(4) of the Refugee Act 1996, as amended, applications for family reunification for dependent family members were also decided on the basis of ministerial discretion. The practical difference between the Act of 1996 and the Act of 2015 is the lack of a specific legal entitlement to apply for extended family members beyond the nuclear family, as well as a lack of entitlement to apply for any family members outside the 12month time limit. However the decision-making process has remained unchanged.

UNHCR observed that many refugees will have spent a significant portion of time in the Irish protection system before obtaining status, during which time they are not allowed access to the labour market. The ability of many refugees to later find employment and successfully fulfil the criteria set down in the general family reunification policy as regards dependent family members may be compromised as a result ${ }^{110}$ (see also Kingston et al., 2013).

UNHCR identifies family reunification as a priority area and as important for successful integration (UNHCR, 2001). ${ }^{111}$ NGOs and international agencies, such

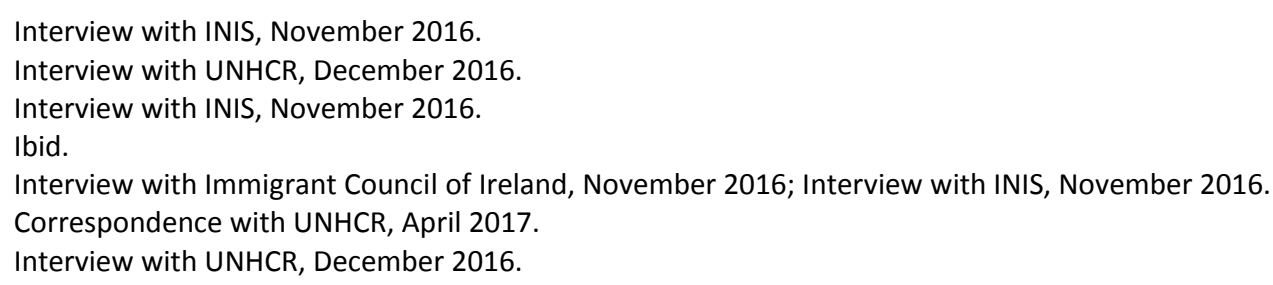


as the Red Cross EU ${ }^{112}$ and UNHCR, have called for increased legal pathways including expanding family reunification. ${ }^{113}$ Crosscare emphasised the importance of facilitating family reunification with extended family for beneficiaries of international protection as sponsors may rely on them to provide additional family support including care and support in childrearing, for example, to allow parents to access the labour market (UNHCR, 2013). ${ }^{114}$ NGOs and UNHCR (Arnold and Quinn, 2016) have expressed concern about the narrowing of those eligible for family reunification brought in under the International Protection Act, 2015.

\subsection{FAMILY-BASED PRIVATE SPONSORSHIP}

The government introduced a once-off scheme in 2014 in response to the crisis in Syria. The Syrian Humanitarian Admission Programme (SHAP) was a family-based private sponsorship scheme which allowed Irish citizens of Syrian birth and Syrian nationals lawfully resident in Ireland to apply to bring family members in Syria or displaced from Syria in surrounding countries, to Ireland. Sponsors could apply between 14 March 2014 and 30 April 2014. Ireland provided permission to reside in Ireland to 119 persons utilising the SHAP scheme (Arnold and Quinn, 2016). Permissions were granted initially for a period of two years, which was not automatically renewable. Furthermore sponsors had to show an ability to support their family members in Ireland. INIS stated that all refused SHAP applications were unsuccessful due to a lack of sufficient financial support/accommodation on the part of the sponsor (Arnold and Quinn, 2016). Nonetheless SHAP was generally seen as a positive initiative (Arnold and Quinn, 2016). ${ }^{115}$ While this scheme allowed Irish nationals of Syrian birth and legally resident Syrian nationals to be joined by family, the beneficiaries, or family members, who arrived in Ireland under this scheme were not able to apply for family reunification in their own right. Various $\mathrm{NGOs}^{116}$ and organisations have called on the government to introduce similar schemes to provide safe, legal pathways for refugees (Arnold and Quinn, 2016).

\subsection{INELIGIBILITY: REJECTION ON GROUNDS OF PUBLIC POLICY, SECURITY AND HEALTH}

The Directive provides for the rejection of family reunification applications on a number of grounds, for example public policy, public security and public health. ${ }^{117}$ In Ireland, applications for family reunification may also be rejected on these grounds.

\footnotetext{
112 Red Cross EU Office, '21 Red Cross National Societies in the European Union call for more legal avenues to access protection' 12 May 2015, www.redcross.eu. Interview with UNHCR, December 2016. See also: Nasc 'Safe Passage [campaign]' www.nascireland.org. Interview with Crosscare, December 2016. Interview with INIS, December 2016.

For example, Nasc, 'Safe Passage' www.nascireland.org.

Article 6 of Directive 2003/86/EC.
} 
Persons may be refused family reunification on grounds of public security if they pose a threat to the State through terrorism or support of terrorist activities or threat of incitement to hatred (INIS, 2016a). In addition, persons may be refused family reunification who pose a risk of criminal behaviour or violence (INIS, 2016a). While having a criminal record does not automatically exclude a person from consideration, it is 'highly influential' in the decision-making process (INIS, 2016a).

Refusals on grounds of public health may arise in the context of contagious diseases for instance in the case of a pandemic or where diseases are subject to the International Health Regulations adopted by the World Health Organisation (INIS, 2016a).

Refusals on grounds of public policy may arise in the case of polygamy. ${ }^{118}$ For example in A.M.A. v. Minister for Justice and Equality an applicant from Somalia, who was recognised as a refugee in 2004, applied for family reunification with his wife in 2005 - this application was granted in 2016. ${ }^{119}$ The applicant separated from his wife in 2009. In August of 2009, he entered into a second marriage with a 16-year-old from Ethiopia. He made an application for family reunification in 2012 for his second wife. This application was refused on grounds that the marriage was not deemed lawful due to the status of the previous marriage and the underage nature of the second marriage. The applicant had also applied for naturalisation in 2007 but this was refused in 2014. The basis for that refusal was that he was not of good character due in part to his traditional marriage to an underage girl and so-called disregard for the family reunification process. By way of judicial review proceedings, the applicant sought to have the naturalisation refusal set aside. During the course of that application, the court considered the legal status of the applicant's two marriages as they were central to the naturalisation refusal.

The application for judicial review was dismissed. In relation to the family reunification application, the Court held that it was an abuse of the family reunification process to make applications for two spouses without any intervening divorce or proof that the second marriage was lawful. 


\subsubsection{Ineligibility in the context of international protection}

Family members of beneficiaries of international protection may also be refused reunification on national security or public policy grounds. The International Protection Act 2015 provides that:

The Minister may refuse to give permission to enter and reside in the State to a person referred to in subsection (4) or revoke any permission given to such a person-

(a) in the interest of national security or public policy ('ordre public'),

(b) where the person would be or is excluded from being a refugee in accordance with section 10,

(c) where the person would be or is excluded from being eligible for subsidiary protection in accordance with section 12,

(d) where the entitlement of the sponsor to remain in the State ceases, or

(e) where misrepresentation or omission of facts, whether or not including the use of false documents, by the person was decisive in the decision to give the person the permission.

All assessments of applications for family reunification pursuant to Sections 56 and 57 of the Act of 2015 involve security checks to assess if any element of the application is inconsistent with national policy, the constitution, government, etc. ${ }^{120}$ Assessments also involve comparing information contained within family reunification applications and that contained within protection applications in order to check for inconsistencies. ${ }^{121}$ Where there are security concerns, files may be referred to the GNIB for further investigation prior to any decision being made. INIS noted that some applications are refused on this basis, but not many. ${ }^{122}$

Issues of public security and health had not arisen in cases dealt with by the Immigrant Council of Ireland. ${ }^{123}$ However Nasc had encountered cases where applications were rejected where family members had been subject to a deportation order from Ireland; had committed an offence; or had made an application for asylum in another Member State. ${ }^{124}$ 


\section{SECTION 4}

\section{Establishing identity and family relationship}

Section 4 outlines the requirements for establishing identity and family relationships as part of the process of applying for family reunification in Ireland.

\subsection{INTRODUCTION}

As part of the application, it must first be established (1) the identity of family members and sponsors and (2) the existence of a family relationship between the sponsor and the family member through documentation and/or DNA testing. INIS provides a list of documentary evidence needed to establish family relationship by category of family member, including birth certificates, marriage certificates, adoption orders and passports (see Table 4.1). All documents must be originals and translated to English where relevant. All applications, including from beneficiaries of international protection, must include a birth certificate, national identification, passport ${ }^{125}$ and two colour passport-sized photographs for each named person in the application. A signed letter of application including full contact details, reason(s) for coming to Ireland, and details of family members in Ireland and any other family members in Ireland or another EU Member State must also be provided. Sponsors must submit a copy of all pages of their passport, copy of registration if applicable, and copy of current employment permit/researcher (scientific) hosting agreement or other evidence of eligibility to sponsor. 
TABLE 4.1 DOCUMENTARY EVIDENCE REQUIRED TO CONFIRM IDENTITY OF FAMILY MEMBERS AND FAMILY RELATIONSHIP WITH SPONSOR

Family Member Evidence

- Divorce/ death certificate of previous spouse(s) (if applicable)

- Marriage/civil partnership certificate

Spouse

- If the sponsor is residing in Ireland and the sponsor and spouse have not resided together since the union, a relationship history must be provided.

- Current passport sized photos stating name of child, date of birth of child and the date the photo was taken

- Statement of Parental Authorisation (granting permission for the child to travel to Ireland) from other parent if not travelling with child to Ireland

Children

- Death certificate of other parent if applicable

- Evidence of sole legal guardianship if an original death certificate is not obtainable (court order bestowing sole custody of the child on the parent concerned)

- Letter of authorisation from current guardian if not in the care of his/her parents.

- Evidence that supports the existence and durability of the relationships (e.g. evidence of common ownership of property, joint tenancy, on-going correspondence addressed to both partners at the same address, financial

De Facto Partner dependence/interdependence or any other relevant documentary evidence)

- Full account of relationship history must be provided (where/when the applicants met evidenced by visa, entry/exit stamps, photographs, correspondence by email/phone, etc.).

- Current passport sized photos stating name of child, date of birth of child and the date the photo was taken (if applicable)

- Marriage Certificates (if applicable)

- Death/Divorce certificates (if applicable)

- Court certified documentary evidence of custodial rights over family member i.e., adopted/fostered child

- Evidence of financial dependency - that the Refugee has been supporting

Other dependent relatives other than those listed above his/her family i.e., money transfer receipts, bank statements, postal orders etc. (amount, frequency and duration of the financial support)

- Evidence of physical and/or mental dependency, i.e. detailed current medical reports containing detailed prognosis (evidence of why the dependent family member is unable to work/not eligible for State benefits)

- Evidence of your current financial and domestic circumstances (any other sources of income)

- Living costs (e.g. evidence of mortgage/rent, utility, food, medical, educationrelated payments)

- Details of any other family members in the country of residence

- Relationship with sponsor (evidence of active and continuous involvement in the family member's life, e.g. evidence of visits, correspondence).

Source: INIS, 'Join Family' www.inis.gov.ie, December 2016.

Providing sufficient documentary evidence to establish the identities of the sponsor and the family members was frequently cited as a challenge in the literature and in interviews with stakeholders. ${ }^{126}$ INIS identified identity as an 
important issue in all areas of immigration. INIS noted that above all they encourage applicant family members and sponsors to supply passports or similar. They noted that where the sponsor (primary applicant) is unable to provide original documentation, such as a passport, national ID, evidence of registration with UNHCR or even a family book, the application could be refused. ${ }^{127}$ Affidavits in place of identification are not accepted. ${ }^{128}$ Forms of identification that are out of date are considered where necessary. ${ }^{129}$ This challenge is more common among applications from beneficiaries of international protection - this group more often do not have passports. ${ }^{130}$

INIS clarified that the submission of any or all of the documents listed in Table 4.1 does not guarantee that the application will be successful. ${ }^{131}$ In the case of refusals due to insufficient documentation, critics have argued that although the reason for refusal may be clearly stated in the decision, the precise documents that are deemed missing or insufficient are not listed. ${ }^{132}$ It is necessary to follow up with INIS in writing in order to obtain this type of further detail. ${ }^{133}$ UNHCR observed that the requirement to provide original documents from abroad can be challenging. For example, if a family member who is also living as a refugee or asylum-seeker in a third country sends their original passport or national ID card to Ireland to be considered under the application, they may risk being stopped by local police without access to original documents. Postal or courier services may also be unreliable. ${ }^{134}$

Nasc noted that quite often official documents from Embassies or Authorities in the country of origin contain mistakes, including spelling mistakes or the wrong date of birth. Having such mistakes corrected and further documents issued can be very time consuming. ${ }^{135}$

\subsection{RELATIONSHIP HISTORY: SPOUSES AND DE FACTO PARTNERS}

Documentation required by INIS varies depending on the type of family member concerned. Marriage or civil partnership certificates are required for husbands, wives and civil partners. Relationship history may be required for spousal partners and de facto partners. The introduction of the Civil Registration (Amendment) Act 2014 and other measures introduced to combat 'sham

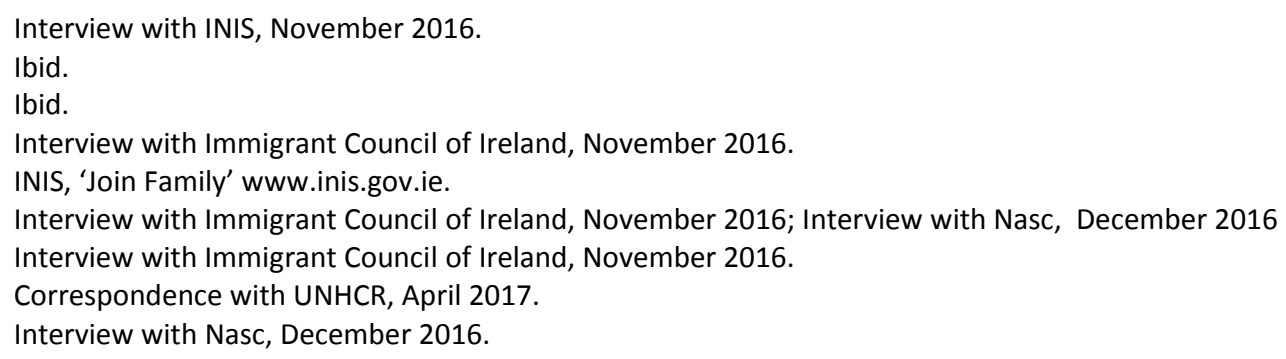


marriages', have resulted in a higher level of scrutiny for establishing the validity of all marriages. ${ }^{136}$

De facto partners must demonstrate a commitment to live together permanently as partners immediately following the outcome of the application or as soon as circumstances permit. A declaration to this effect forms part of the application. ${ }^{137}$ De facto partners are not provided for in international protection legislation. However beneficiaries of international protection may apply for family reunification using the administrative procedures where the application falls outside the scope of Sections 56 and 57 of the International Protection Act 2015 (see Section 3.5). Unlike the provisions for nuclear family under the Act of 2015, decisions are made on the basis of discretion.

Evidence of at least two face-to-face meetings between sponsor and applicant must be provided. NGOs have observed that this can be a challenge due to, for example, religious restrictions and cultural norms in the context of dating. ${ }^{138}$

Screen grabs and evidence produced from social media platforms have become accepted forms of documentation to support the relationship link. ${ }^{139}$ This was identified as a move to better reflect the reality of transnational communication. ${ }^{140}$

The length of time families have been separated may impact upon the outcome of the application. The Policy Document noted that 'a family member who has been long separated from a person resident in Ireland may have a weaker claim on reunification than one where the parties have until recently been a close family unit' (INIS, 2016a).

\subsection{CHILDREN}

A combination of legal documents and DNA testing (see Section 4.6) is often required in order to establish a family relationship between the sponsor and dependent children. As discussed above, the working definition of eligible children includes step-children and adopted children. INIS requires legal documentation demonstrating adoption, ward or guardianship and applications

\footnotetext{
136 Interview with Immigrant Council of Ireland, November 2016.

137 INIS (2013). Policy Document on Non-EEA Family Reunification.

138 Nasc and $\mathrm{ICl}$ note that this requirement can pose a problem for couples who are from certain religious communities. Furthermore, it can be difficult generally to provide evidence of meeting face-to-face. ICI note that there is very little in the guidance (Policy Document) to assist applicants in demonstrating this requirement. $\mathrm{ICl}$ note that applicants may submit a narrative in the absence of any formal evidence. 
without this documentation are not facilitated. ${ }^{141}$ The applicant must also show that the dependent child is a full-time member of the sponsor's household. ${ }^{142}$

In matters of joint custody, the other parent must provide written consent that the child can reside in Ireland. However no rights are conferred onto the other parent to visit or reside in Ireland (INIS, 2016a). In the case of separation, INIS requires consent from the family member not intending to enter and reside with their child in Ireland. ${ }^{143}$ Immigrant Council of Ireland described the approach taken to assess the authenticity of court documents concerning transferring guardianship of children and consent of another parent for the child to leave the jurisdiction as a welcome safeguard. ${ }^{144}$

In the case of unaccompanied minors, the Child and Family Agency, Tusla, acts on the child's behalf and part of their role is to look after the best interests of the child. ${ }^{145}$ INIS noted that they also must be guided by the best interest of the child. Applications for family reunification are submitted to INIS by a representative of Tusla. In the case of accompanied children, their parents fill this role. ${ }^{146}$

As discussed in Section 3, children may also apply to be joined by their parents. Critics have argued that these applications should be prioritised (Kenny, 2011). Critics have also expressed concern that establishing dependency for child sponsors is a challenge (Kenny, 2011). This concern is illustrated in the case, A.A.M. [Somalia] v. The Minister for Justice and Equality, concerning a refugee who arrived to Ireland as an unaccompanied minor. ${ }^{147}$ The child was recognised as a refugee in 2007. He applied for family reunification with his mother and four siblings under Section 18(4) (dependent family members) of the Refugee Act 1996 , as amended. He sent his family $€ 157$ per month. The Minister refused his application for family reunification on grounds that the family members were not financially dependent on the principal applicant. The applicant challenged the decision by way of judicial review. The High Court referred to Directive 2003/86/EC, noting that while Ireland does not participate in the Directive,

it is nevertheless of value to consider that the Directive allows Member States which are party to it to impose pre-conditions for the family reunification of refugees who fail to apply promptly for family reunification referring in particular to Article 7. The High Court judge stated;

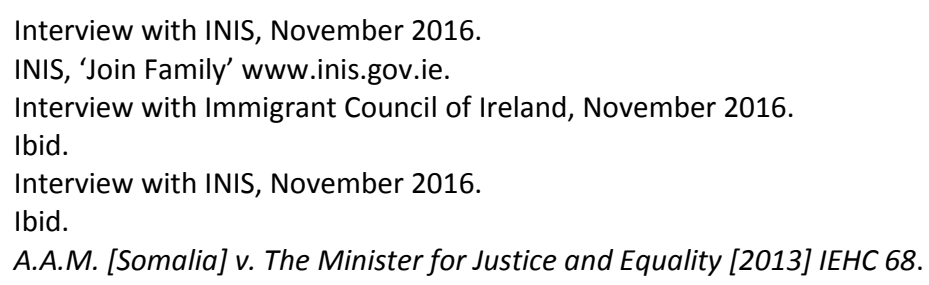


In contrast to the total absence of guidance which is available to refugees whose status has been recognised in this State, refugees recognised by other Member States of the EU who have transposed the family reunification Directive 2003/86/EC will be fully aware which, if any, of the criteria outlined in Article 7 of that Directive apply. If a refugee has not acted promptly and cannot meet those criteria, then a goal can be set for achievement in the future by rapidly seeking employment. If that option is not available, the refugee can be resigned to sending remittances and the waiting expectant family members can adjust their expectations. No such clarity is available for such persons in this State who, if fortunate enough to find a solicitor and barrister to act pro bono, can raise a legal challenge before the Court and if successful can attempt to persuade the Minister for a second time that the circumstances exist for him to exercise his discretion and that he should exercise that discretion in favour of the refugee. Others wait until hope fades. Such a process lacks clarity or transparency and cannot be fair. The system calls for an overhaul. Time and money could be saved if the Minister were to draw up guidelines on what is required to establish 'dependency' and, where such dependency is established, under what conditions family members will be permitted to join the refugee.

The High Court held that the Minister must establish an objective 'yard stick' to determine dependency as it was not sufficient to speculate or apply Irish norms when assessing cost and standard of living. The High Court also held that the rationale that the applicant would not be able to support the family in Ireland provided by the Minister was not relevant when assessing dependency. The Minister's decision was quashed.

\subsection{OTHER DEPENDENT RELATIVES}

According to INIS, other dependent relatives may include mothers, fathers, brothers, sisters, children, grandparents, wards and guardians. The Policy Document defines 'dependency' to mean that the family member is

(i) supported financially by the sponsor on a continuous basis and (ii) that there is evidence of social dependency between the two parties. The degree of dependency must be such as to render independent living at a subsistence level by the family member in his/her home country impossible if that financial and social support were not maintained. A minor child living with its parents will be automatically assumed to be their dependant (INIS 2016a).

Research has pointed to difficulties associated with adherence to a strict interpretation of 'dependent family member' by decision-makers and within that a narrow interpretation of the notion of 'dependency' and the restrictive exercise 
of discretion. ${ }^{148}$ 'Dependency' has been interpreted in various High Court judgments during the study reference period (2011-2016).

In A.M.S. v. Minister for Justice and Equality, the (Somali) applicant/respondent was declared a refugee in Ireland in $2009 .{ }^{149}$ He made two applications for family reunification in respect of his mother and minor sister in 2011 and 2012. The first application was refused, challenged to the High Court by way of judicial review and quashed and remitted to INIS. The second application in 2012 was also refused and challenged following the same process. The decision of the Minister was again quashed. The High Court argued that the analysis of dependency must not be confined to financial support, arguing that the concept also involves issues of identity and relationship. The Minister appealed that decision to the Supreme Court. The two overarching points of law under dispute were: (1) the interpretation of Section 18 of the Refugee Act 1996 by the trial judge that family reunification under that section could not be refused on the grounds that such person or persons would likely be dependent on the State for material support and (2) the question of proportionality of the decision of the Minister in refusing family reunification in the circumstances of the case.

While the Supreme Court held that the Minister's discretion under Section 18(4) allowed for consideration of the potential financial consequences for the State of allowing such a family reunification application, the weighing of those consequences against the consequences for the applicant family had been done disproportionately. Another example is the case of F.B. v. The Minister for Justice \& Equality, which looked at the impact of the applicant's small remittances had on the beneficiaries and whether or not it could be construed as establishing dependency. ${ }^{150}$ This case concerned a Nigerian woman who was recognised as a refugee in 2008 and became an Irish citizen in 2013. The applicant applied to be joined by her two granddaughters pursuant to Section 18 of the Refugee Act 1996, as amended (dependent family members). The application was refused on grounds that the grandmother did not show that the granddaughters were financially dependent on her.

The applicant challenged the decision by way of judicial review. The High Court found that the Minister did not apply the appropriate test as to whether or not the grandchildren were dependent on the applicant. The Minister did not assess whether or not the small amount remitted would indeed impact upon the lives of the grandchildren. The court also argued that the other aspects of dependency 
established in A.M.S. (see above) were not considered. Lastly, the High Court held that the Minister erred in law by not considering the other rights the applicant and grandchildren have pursuant to Article 8 of the European Convention. The Minister's decision was quashed.

The abovementioned cases refer to applications made under Section 18(4) of the Refugee Act 1996. Section 18(4) provided for the possibility of family reunification for beneficiaries of international protection with other dependent family members at the discretion of the Minister. The Refugee Act 1996 has been replaced by the Act of 2015 and the provision relating to dependent family members was not carried over (see Section 3.5). The category of eligible family members is now restricted to nuclear family only. These cases nevertheless inform on the discourse relating to dependency.

\subsection{FAMILY MEMBERS OF BENEFICIARIES OF INTERNATIONAL PROTECTION}

INIS (2016b) published The International Protection Act 2015 - Family Reunification Information in January 2016, outlining the documents needed to substantiate a family reunification application submitted under Sections 56 and 57 of the Act of 2015. The list is similar to that provided for all non-EEA applicants, but additional documentation is required for spousal applications ${ }^{151}$ to prove that the relationship was established prior to the date on which the sponsor applied for international protection. ${ }^{152}$

As mentioned above, evidence of marriage must be provided for family reunification with spouses. Generally marriages must be legally contracted, entered into freely and capable of recognition under Irish law (INIS, 2016). The International Protection Act 2015 does not require that marriages between family members and beneficiary of international protection sponsors are capable of recognition under Irish law.

Marriage certificate stamped by the relevant authority - if married more than once applicants must provide both or all marriage certificates; any other evidence, for example, dowry agreement; marriage book, - if married more than once the applicant must provide both or all marriage books; receipt for any registration fees paid for marriage (if applicable); documentary evidence of shared resources (including joint bank accounts) if applicable; documentary evidence, if any, of money transfers from applicant to spouse; final decree of divorce or nullity; spouse's final decree of divorce or nullity; death certificate of previous spouse(s); death certificate of spouse's previous spouse(s). 
In M. v. F., ${ }^{153}$ the applicant, a father from Zimbabwe, who was declared a refugee in 2007 applied for family reunification for his wife and two daughters. His daughters were permitted to reside in Ireland on foot of positive decisions for their reunification. The application for the refugee's wife was refused on the basis that it was customary and 'does not appear to be valid under Irish law'. The applicant was advised that he could seek a declaration of the marriage pursuant to Section 29 of the Family Law Act 1995, as amended in the Circuit Court, following which the application might be reviewed. The applicant was informed that there was no appeal process open to him.

The Circuit Court was opposed to the granting of such a declaration of validity as the marriage was customary and therefore potentially polygamous and thus not valid under Irish law, but ultimately issued the declaration. The declaration was challenged by the Attorney General to the High Court.

The High Court decision was that the use of Section 29 of the Family Law Act 1995 was inappropriate and should not be used in family reunification applications concerning refugees, thus refusing the appeal by the Attorney General. The High Court nevertheless upheld the decision of the Circuit Court. In particular, the High Court held that, when considering recognition of a marriage for the purposes of a family reunification application, a marriage should be recognised 'where the parties to the marriage had the capacity to enter the marriage under their respective lex domicilii and the marriage complies with the formalities required under the lex loci celebrationis', i.e. where the marriage is recognised according to the laws and customs of the place in which it is contracted.

Although M. v. F. pertains to the Refugee Act 1996, it is still somewhat relevant as no provision was included in the Act of 2015 requiring marriages to be recognised under Irish law.

\subsection{DNA TESTING}

In the absence of documentation confirming family relationship, INIS may suggest DNA testing ${ }^{154}$ and provide information about a DNA service provider, which operates in Ireland and in the country of residence of the family member. INIS covers the cost of the tests initially. If the outcome is negative, INIS will seek to recover the costs from the applicant. DNA testing may sometimes be suggested by INIS even where documentation is provided. 
INIS and some NGOs have characterised DNA testing as positive, as it has helped get some applications 'over the line' ${ }^{155}$ and is an example of an additional safeguard in cases concerning children. ${ }^{156}$ Nasc also commented that DNA testing is much more efficient now compared to previous years. ${ }^{157}$ However some NGOs commented that persons may find attending DNA testing centres in their countries of origin challenging. ${ }^{158}$ INIS stated that they have not received any complaints in this regard over the last three years, during which time the same service provider has been used. ${ }^{159}$ 


\section{SECTION 5}

\section{Access to rights following family reunification}

Section 5 describes the rights and entitlements that flow from permission to remain in Ireland for family reasons, specifically family members' access to the labour market, education and vocational training, social welfare, public health care and housing, and naturalisation.

\section{$5.1 \quad$ INTRODUCTION}

All third-country nationals legally resident in Ireland, including those whose residency is for family reasons, may access mainstream integration services. The level of supports and entitlements varies depending on the permission granted to the family member, the relationship to the sponsor and the status of the sponsor, as discussed below. There are no targeted integration supports for non-EEA nationals, with the exception of Programme Refugees. Information and support in accessing public services, including education, form part of the orientation programme provided to Programme Refugees (Arnold and Quinn, 2016). Cultural information is also part of the orientation programme for resettled refugees, which is regarded as beneficial (Arnold and Quinn, 2016; Ní Raghallaigh et al., 2016).

Commentators and organisations have observed a number of challenges associated with the arrival of family members wishing to start a new family life together in Ireland (Arnold and Quinn, 2016) and recommend more support for sponsors to prepare for the arrival of family members. Supports may include: information on where/how to access services; ${ }^{160}$ information on cultural practices in Ireland (Immigrant Council of Ireland, 2012), including as regards parenting ${ }^{161}$ and support to overcome challenges arising due to protracted separation. ${ }^{162}$ Crosscare has developed a leaflet on family reunification for refugees to try to fill this information gap. ${ }^{163}$

Various NGOs provide integration support. ${ }^{164}$ UNHCR, Irish Red Cross and the IOM support a limited number of family members and their sponsors benefitting from the Travel Assistance Scheme by assisting them with the costs and logistics 
of travel to Ireland. However, UNHCR commented that the programme is not designed to extend any particular supports after arrival in Ireland. ${ }^{165}$

\subsection{INTEGRATION IN EMPLOYMENT, HOUSING, EDUCATION AND HEALTH}

Integration takes place in four main domains, namely: employment, housing, education and health (Ager and Strand, 2008). The Directive stipulates that family members are entitled (in the same way as the sponsor) to access education, employment and self-employed activities as well as vocational guidance and training. This section therefore outlines family members' access to rights following family reunification within Article 14 of the Directive and each domain, reflecting on the challenges discussed above.

\subsubsection{Labour market}

Immediate family of Irish/EU citizens and family members of beneficiaries of international protection may access employment and self-employed activities without restriction. Family members of other categories of Non-EEA nationals may also access the labour market without having to apply for an employment permit such as: investors/entrepreneurs and persons with business permission (Gusciute et al., 2015). ${ }^{166}$ Family members in these cases are issued Stamp 4 immigration permission. In addition beneficiaries of the SHAP scheme may access the labour market immediately on arrival. They are issued Stamp SHAP immigration permission.

Immediate family members of non-EEA nationals other than those listed above may in some cases access employment. Family members are issued Stamp 3 immigration permission, entitling them to apply for immigration status in their own right (i.e. for permission on the basis of education, employment, business permission, etc.). Family members in this case are subject to employment permit requirements operated by the Department of Jobs, Enterprise and Innovation.

Some recent changes in policy and law have sought to ease the transition from Stamp 3 permission to an employment permit. For example, the dependant/ partner/spouse employment permit provides greater ease of access by removing some restrictions, namely: persons may apply for employment permits for all occupations; remuneration can be less than $€ 30,000$ per annum (but not less than the National Minimum Wage); the prospective employer is not required to undertake a Labour Market Means Test; and the application is free of charge. ${ }^{167}$ 
Although it is possible for family members who were initially issued with Stamp 3 permission to access the labour market, Crosscare observed that the need to apply for an employment permit is still a barrier. Employers may not be willing to go through the application process. ${ }^{168}$

Other barriers to accessing employment include inadequate English language skills; poor links or contacts to facilitate access to the labour market; ${ }^{169}$ lack of recognition of qualifications; and potential need to up-skill (see also Gusciute et al., 2016). ${ }^{170}$

\subsubsection{Education and vocational education}

Child family members, who are under the age of 18 , may access primary and secondary education. Crosscare noted that they do not come across significant problems in respect of children accessing first and second level education. ${ }^{171}$

Access to education at third level was identified as a challenge as students may not satisfy the habitual residence condition, making them ineligible to avail of the 'free fees' scheme, ${ }^{172}$ EU-level fees and/or apply for a grant. ${ }^{173}$ The term 'habitually resident' means that the person is residing in Ireland and has a proven close link to the state. In order to prove this link, non-EEA nationals must have a right to reside; their length of time spent in Ireland, continuity of residence and nature of residence are also taken into account (Quinn et al., 2014). ${ }^{174}$ In practice family members of beneficiaries of international protection must reside in the country for three years before they are eligible to access free tuition fees for third-level education on the same basis as habitually resident Irish citizens. Crosscare identified this as the primary barrier to accessing third-level education experienced by family members of beneficiaries of international protection. ${ }^{175}$

Adult family members may also access language, educational, and vocational courses through existing mainstream services, such as those provided by the Education and Training Boards (Gusciute et al., 2016). However access to English language classes and supports were identified as a challenge (Gusciute et al.,

Interview with Crosscare, December 2016.

Crosscare referred to the fact that some communities would have a bigger presence in Ireland, such as the Chinese community.

Crosscare noted that the sponsor would tend to be the most highly skilled.

Interview with Crosscare, December 2016.

Citizens Information, 'Third-level student fees and charges', www.citizensinformation.ie.

Interview with UNHCR, December 2016; Interview with Nasc, December 2016; Interview with Crosscare, December 2016.

Citizens Information 'Residence requirements for social assistance in Ireland, www.citizensinformation.ie.

Interview with Crosscare, December 2016. 
2016) in particular for categories of third-country nationals who are not beneficiaries of international protection. ${ }^{176}$

\subsubsection{Social welfare, public health care and housing}

As outlined in Section 3, non-EEA family members, including beneficiaries of SHAP (Arnold and Quinn, 2016), are typically not eligible to avail of non-insurance based social welfare benefits or housing services by a housing authority, with the exception of family members of beneficiaries of international protection. Beneficiaries of international protection have most of the same rights as an Irish citizen and are deemed to be compliant with the habitual residence condition. ${ }^{177}$ Family members of beneficiaries are granted a permit derived from the sponsor. Family members are entitled to remain in the State and to the same rights and privileges as a person with an international protection status for as long as the sponsor is entitled to remain in the State. Family members of all categories of non-EEA nationals, including beneficiaries of international protection, are not deemed to be automatically compliant with the habitual residence condition. ${ }^{178}$

The same applies in the context of health care. Family members would normally be required to present evidence of private health insurance cover when registering for immigration permission on arrival. Evidence of private health insurance cover forms part of the application for family reunification with elderly parents (see Section 3.4.2). Family members of beneficiaries of international protection, however, have an automatic right to social healthcare and are eligible to apply for medical cards. ${ }^{179}$

The housing crisis has also affected family members of non-EEA sponsors. ${ }^{180}$ Crosscare may assist families who need to find adequate accommodation. ${ }^{181}$

Crosscare observed that beneficiaries of international protection can face particular challenges in relation to homelessness. While other migrants have to satisfy minimum income requirements and therefore must prove that they can financially support family members, beneficiaries of international protection may not have sufficient resources to support family members. Such persons may be dependent on homeless accommodation, including in cases where the sponsor is still in Direct Provision (State provided accommodation for persons seeking

Ibid.

Citizensinformation.ie.

Interview with Crosscare, December 2016.

Patients with medical cards do not need to pay GP visit fees or other healthcare contributions associated with treatments.

Interview with Crosscare, December 2016; Interview with UNHCR, December 2016.

Ibid. 
asylum). Crosscare noted that living in homeless accommodation also makes accessing the labour market and engaging with education more difficult. ${ }^{182}$

Crosscare warned that the introduction of the one-year post-decision time limit for making an application under the International Protection Act 2015 will exacerbate this problem - sponsors may not be able to wait until they are in a position to provide financially for family members before making an application for reunification. ${ }^{183}$

\subsection{CITIZENSHIP}

All Non-EEA nationals with five years reckonable residence are eligible to apply for Irish citizenship. Refugees may apply after three years. Family members of beneficiaries of international protection must comply with the five-year rule. Elderly parents of sponsors are issued with a Stamp 0 permission that is not reckonable for the purposes of naturalisation (INIS, 2016a). Non-EEA family members of Irish citizens are eligible for family reunification. 


\section{SECTION 6}

\section{Conclusion}

Family reunification is one of the main reasons for immigration into the EU. It is an avenue through which those already legally resident in a Member State may be joined by their family. Family reunification has a positive impact on social, cultural and economic stability and cohesion in the host country, as well as the integration of family members and sponsors. ${ }^{184}$ In the context of the current refugee and migrant crisis, the European Commission has endorsed the full use of existing safe legal avenues, ${ }^{185}$ including family reunification programmes, while UNHCR and NGOs have called for the expansion of such schemes. Family reunification is one example of a legal pathway for people in displacement to reach safety.

This study investigates non-EEA family reunification in Ireland between 2011 and 2016. The study focuses on policy, law and practice in Ireland, considering recent changes in law and guidance.

The best available data on the 'stock' of non-EEA family members in Ireland are residence permits issued for family-related reasons. In 2015 just over 25,600 residence permits were held in Ireland by non-EEA family members, representing 23 per cent of total permits held. In the EU as a whole, family members accounted for 38 per cent of total permits issued in the same year. Residence permits issued for the first time provide information on the 'flow' of non-EEA family members coming Ireland for the first time. In 2015 just over 3,400 such permits were issued in Ireland, representing 9 per cent of first permits issued. First residence permits issued for family-related reasons represented the smallest category of permits issued, coming after education, employment and other. In contrast permits issued for family-related reasons formed the largest category of permits issued in the EU, accounting for 29 per cent of total new permits issued.

Ireland's family reunification policy and legislation differs from that in place across the EU. Non-EEA family reunification at the EU level is governed by Council Directive 2003/86/EC of 22 September 2003 on the right to family reunification (Directive) in all Member States except Denmark, Ireland and the United Kingdom. In Ireland family reunification (excluding for international protection 
beneficiaries) is governed by the INIS Policy Document on Non-EEA Family Reunification and operates largely on the basis of Ministerial discretion. NGOs argue that, on the one hand, a lack of a legislative entitlement to reunification and the reliance on discretion has resulted in inconsistencies in decision-making. On the other hand, NGOs and decision-makers also noted that discretionary decision-making may benefit the applicant; for example income requirements may be waived on a case-by-case basis.

At present the only type of family reunification that is on a legislative basis in Ireland is for beneficiaries of international protection. Applications from beneficiaries of international protection are processed pursuant to the International Protection Act 2015. While Ireland exercised its right not to participate in the Directive, INIS has noted that Sections 56 and 57 of the Act of 2015 were drafted in line with the provisions of the Directive. In addition the Directive has been referred to in High Court judgments in the context of international protection and in particular around the concept of 'dependency'.

Prior to the International Protection Act 2015 which replaced the Refugee Act 1996, family reunification for beneficiaries of international protection in Ireland was seen as more generous than the Directive. The Act of 2015 brought about significant changes, removing the pre-existing category of dependent relatives and narrowing eligibility to spouses and children (and minor siblings in applications by unaccompanied minors). In the past dependent family members, including grandparents, parents, brothers, sisters, grandchildren, and guardians were eligible pursuant to Section 18(4) of the Refugee Act 1996. The removal of this category in the Act of 2015 has been widely criticised by NGOs and UNHCR. INIS expressed the view that the revised practices will increase efficiency in processing and reduce waiting times.

Under the Act of 2015, beneficiaries of subsidiary protection are entitled to family reunification in the same way as refugees. Not all Member States extend the right to family reunification to beneficiaries of subsidiary protection. In addition applications must be made within 12 months of a grant of international protection. The equivalent provision under the Family Reunification Directive allows for Member States to apply a limit of three months.

For the purposes of applying for family reunification, evidence of the identity of the sponsor and family members, and the family relationships between the sponsor and the family member, must be provided. Applicant family members and sponsors can encounter a number of difficulties providing adequate evidence, relating to gathering documents from the country of origin, fulfilling 
DNA testing requirements (where applicable) and completing forms and online visa applications.

INIS and NGOs noted that applications for family reunification are labour intensive. NGOs reported increased requests for support from persons applying to be joined by family in 2016 . They also observed that no targeted legal service exists.

No targeted integration support measures are in place for family members although depending on the status of their sponsor, they may access mainstream services. NGOs emphasised the importance of providing orientation and integration supports for families and sponsors to overcome some of the initial challenges arising from protracted periods of separation, cultural differences, language competence and access to adequate housing. 


\section{REFERENCES}

Ager A. and A. Strang (2008). 'Understanding Integration: A Conceptual Framework'. Journal of Refugee Studies. 21(2).

Arnold, S. and E. Quinn (2016). Resettlement of Refugees and Private Sponsorship in Ireland. Research Series No. 55. Dublin: European Migration Network. Economic and Social Research Institute.

Barrett, A., F. McGinnity and E. Quinn (eds.) (2017). Monitoring Report on Integration 2016. Dublin: Economic and Social Research Institute.

Brazil, P. (2009). 'Recent Issues in Family Reunification Under Irish Law', The Researcher 4(2).

Department of Jobs, Enterprise and Innovation (n.d). 'Dependant/Partner/Spouse Employment Permit', www.djei.ie/en/What-We-Do/Jobs-Workplace-and-Skills/EmploymentPermits/Permit-Types/Dependant-Partner-Spouse-Employment-Permit.

Department of Justice and Equality (2017). The Migrant Integration Strategy: A Blueprint for the Future. Dublin: Department of Justice and Equality.

European Commission (2008). Report from the Commission to the European Parliament and the Council on the application of Directive 2003/86/EC on the right to family reunification. Brussels: European Commission.

European Migration Network (2014). Asylum and Migration Glossary 3.0. Brussels: European Migration Network.

European Migration Network (2017). Family Reunification of Third-Country Nationals in the EU plus Norway: National Practices. Brussels: European Migration Network.

Finn, F. (2017). 'Family Reunification, A Perspective from Nasc's Legal Clinics' in Ireland's Response to the Global Refugee and Migration Crisis: From International Protection to National Integration. Dublin: Irish Human Rights and Equality Commission.

Gotzelmann, C. (2016). 'The Implementation and Administration of Family Reunification Rights in Ireland' Irish Jurist LV.

Gusciute, E., E. Quinn and A. Barrett (2015). Business Migration to Ireland. European Migration Network. Research Series No. 43, Dublin: The Economic and Social Research Institute.

Gusciute, E., S. Arnold and E. Quinn (2016). Integration of Beneficiaries of International Protection into the Labour Market: Policies and Practices in Ireland. European Migration Network. Research Series No. 52, Dublin: The Economic and Social Research Institute.

Huddleston, T., Ö. Bilgili, A. Joki and Z. Vankova (2015). Migrant Integration Policy Index 2015. Barcelona and Brussels: Barcelona Centre for International Affairs (CIDOB) and Migration Policy Group.

Immigrant Council of Ireland (2012). Family Reunification a barrier or facilitator of integration? Dublin: Immigrant Council of Ireland.

INIS (2013). Policy Document on Non-EEA Family Reunification. Dublin: Department of Justice and Equality. 
INIS (2016a). Policy Document on Non-EEA Family Reunification. Dublin: Department of Justice and Equality.

INIS (2016b). The International Protection Act 2015 - Family Reunification Information. Dublin: Dublin: Department of Justice and Equality.

INIS, (n.d.). 'Countries whose nationals are visa required' www.inis.gov.ie. www.inis.gov.ie/en/INIS/Pages/Countries+whose+nationals+are+v isa+required.

INIS (n.d.). 'Visa Appeals' www.inis.gov.ie www.inis.gov.ie/en/INIS/Pages/Visa\%20Appeals.

The Irish Times (2017). 'High numbers of Syrians and Iraqis refused family visas', 17 February 2017. www.irishtimes.com.

Kenny, C. (2011). 'Positive, humane and expeditious? An analysis of Ireland's implementation of its obligations in relation to family reunification under the $\mathrm{CRC}^{\prime}$. Northern Ireland Legal Quarterly. 62(2).

Kingston, G., P. O'Connell and E. Kelly (2013). Ethnicity and Nationality in the Irish Labour Market: Evidence form the QNHS Equality Module 2010. The Equality Authority and the ESRI.

Murphy, C. (2011). 'Immigration and Family Life: Family Reunification in Irish Law' Dublin University Law Journal 34.

Ní Raghallaigh, M., M. Foreman and M. Feeley (2016). Transition from Direct Provision to life in the community: The experiences of those who have been granted refugee status, subsidiary protection or leave to remain in Ireland, Dublin: University College Dublin.

OECD (2016). International Migration Outlook 2016, Paris: OECD.

Quinn, E., E. Gusciute, A. Barrett and C. Joyce (2014). Migrant Access to Social Security and Healthcare: Policies and Practice in Ireland. European Migration Network. Dublin: The Economic and Social Research Institute.

Quinn, E. and E. Gusciute (2013). Attracting Highly Qualified Third-Country Nationals: Ireland. Dublin: European Migration Network. Economic and Social Research Institute.

Quinn, E. (2011). Visa Policy as Migration Channel: Ireland. European Migration Network. Dublin: The Economic and Social Research Institute.

Spijkerboer, T. (ed.) (2013). Fleeing Homophobia: Sexual Orientation and Gender Identity and Asylum. New York: Routledge.

UNHCR (2001). Protecting the Family: Challenges in Implementing Policy in the Resettlement Context. Geneva: UNHCR.

UNHCR (2013). A New Beginning: Refugee Integration in Europe. Brussels: UNHCR. 


\section{ANNEX I}

TABLE A1.1 APPLICATIONS FOR FAMILY REUNIFICATION BY INDIVIDUAL FAMILY MEMBER OF BENEFICIARY OF INTERNATIONAL PROTECTION SPONSOR, 2011-2016

\begin{tabular}{|c|c|c|c|c|c|c|c|c|c|c|c|c|c|c|c|c|c|c|}
\hline Year & \multicolumn{3}{|c|}{2011} & \multicolumn{3}{|c|}{2012} & \multicolumn{3}{|c|}{2013} & \multicolumn{3}{|c|}{2014} & \multicolumn{3}{|c|}{2015} & \multicolumn{3}{|c|}{$\begin{array}{l}2016 \text { (up to } \\
\text { and including } \\
24 / 11 / 2016 \text { ) }\end{array}$} \\
\hline $\begin{array}{l}\text { Status by } \\
\text { individual }\end{array}$ & $\frac{\frac{\omega}{10}}{\sum}$ & 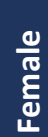 & $\begin{array}{l}\bar{乛} \\
\stackrel{0}{\circ}\end{array}$ & $\frac{\frac{0}{N 0}}{\sum}$ & $\frac{0}{\frac{0}{N}}$ & $\begin{array}{l}\bar{乛} \\
\stackrel{0}{\circ}\end{array}$ & $\frac{\frac{0}{N 0}}{\sum}$ & $\begin{array}{l}\frac{0}{\mathrm{~N}} \\
\frac{\mathrm{E}}{4} \\
\end{array}$ & 항 & $\frac{\omega}{\frac{0}{0}}$ & $\frac{\frac{\omega}{N D}}{\frac{\delta}{0}}$ & 롱 & $\frac{\frac{\omega}{10}}{\Sigma\left(\frac{10}{\Sigma}\right.}$ & 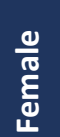 & 홍 & $\frac{\frac{\omega}{\sigma 0}}{\Sigma}$ & 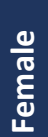 & $\begin{array}{l}\bar{乛} \\
\stackrel{0}{0}\end{array}$ \\
\hline
\end{tabular}

Beneficiaries

of Intl.

protection -

$\begin{array}{llllllllllllllllll}398 & 591 & 989 & 300 & 420 & 720 & 289 & 367 & 656 & 139 & 171 & 310 & 269 & 377 & 646 & 231 & 273 & 504\end{array}$

Refugees

Beneficiaries

of Intl.

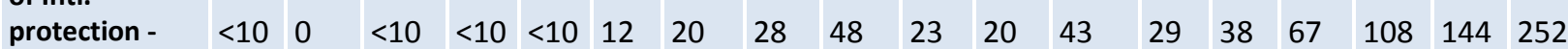

Subsidiary

Protection

Beneficiaries

of intl.

protection:

$\begin{array}{llllllllllllllllll}399 & 591 & 990 & 304 & 428 & 732 & 309 & 395 & 704 & 162 & 191 & 353 & 298 & 415 & 713 & 339 & 417 & 756\end{array}$

Combined

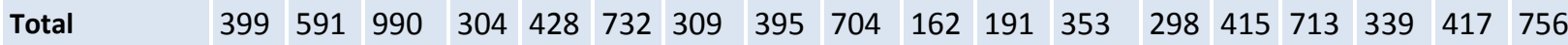

Source: $\quad$ Family Reunification Unit, Irish Naturalisation and Immigration Service, 2016.

TABLE A1.2 SUCCESSFUL APPLICATIONS FOR FAMILY REUNIFICATION BY INDIVIDUAL FAMILY MEMBER OF BENEFICIARY OF INTERNATIONAL PROTECTION SPONSOR, 2011-2016

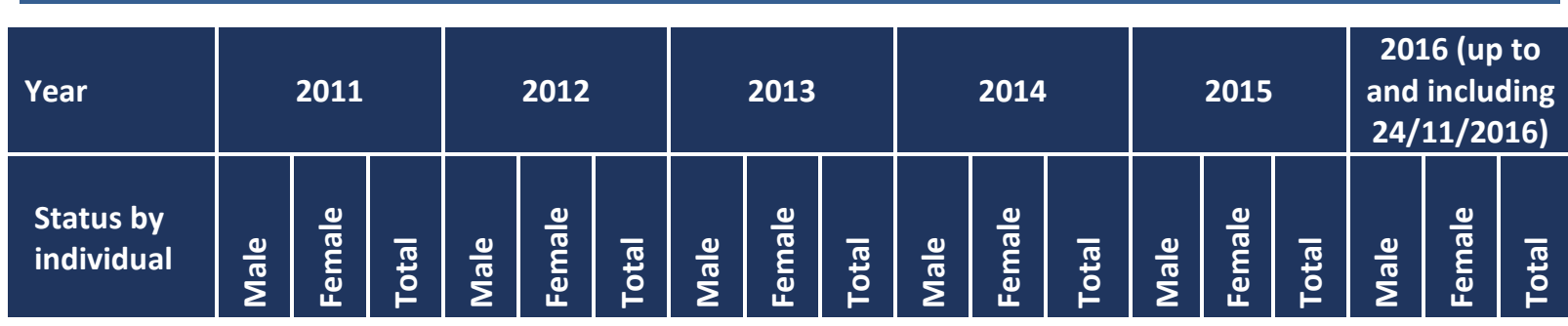

Beneficiaries

of Intl.

protection -

$\begin{array}{llllllllllllllllll}205 & 342 & 547 & 143 & 234 & 377 & 72 & 120 & 192 & 81 & 110 & 191 & 120 & 172 & 292 & 127 & 150 & 277\end{array}$

Refugees

Beneficiaries

of Intl.

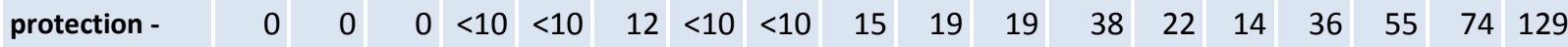

Subsidiary

Protection

Beneficiaries

of intl.

protection:

Combined

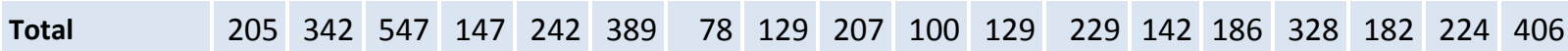

Source: Family Reunification Unit, Irish Naturalisation and Immigration Service, 2016. 
TABLE A1.3 REJECTED APPLICATIONS FOR FAMILY REUNIFICATION BY INDIVIDUAL FAMILY MEMBER OF BENEFICIARY OF INTERNATIONAL PROTECTION SPONSOR, 2011-2016

\begin{tabular}{|c|c|c|c|c|c|c|c|c|c|c|c|c|c|c|c|c|c|c|}
\hline Year & \multicolumn{3}{|c|}{2011} & \multicolumn{3}{|c|}{2012} & \multicolumn{3}{|c|}{2013} & \multicolumn{3}{|c|}{2014} & \multicolumn{3}{|c|}{2015} & \multicolumn{3}{|c|}{$\begin{array}{l}2016 \text { (up to } \\
\text { and including } \\
24 / 11 / 2016 \text { ) }\end{array}$} \\
\hline $\begin{array}{l}\text { Status by } \\
\text { individual }\end{array}$ & $\frac{\omega}{\frac{1}{N 0}}$ & 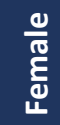 & 항 & $\frac{\omega}{\frac{\omega}{10}}$ & $\frac{0}{\text { है }}$ & હே & $\frac{0}{\frac{10}{\Sigma}}$ & $\begin{array}{l}\frac{0}{\pi / 0} \\
\frac{\mathrm{J}}{4} \\
\end{array}$ & 『ே & $\frac{\omega}{\frac{\omega}{10}}$ & $\frac{\omega}{\frac{\omega}{D}}$ & 항 & $\frac{\omega}{\frac{1}{10}}$ & $\begin{array}{l}\frac{\omega}{\pi} \\
\frac{1}{10}\end{array}$ & 항 & $\frac{0}{\sum}$ & 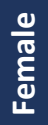 & 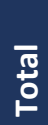 \\
\hline
\end{tabular}

Beneficiaries

of intl.

protection -

$\begin{array}{llllllllllllllllll}90 & 105 & 195 & 138 & 162 & 300 & 172 & 198 & 370 & 40 & 38 & 78 & 121 & 154 & 275 & 85 & 91 & 176\end{array}$

Refugees

Beneficiaries

of intl.

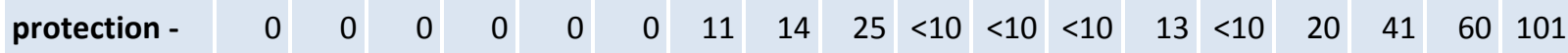

Subsidiary

Protection

Beneficiaries

of intl.

protection:

$\begin{array}{llllllllllllllllll}90 & 105 & 195 & 138 & 162 & 300 & 183 & 212 & 395 & 44 & 39 & 83 & 134 & 161 & 295 & 126 & 151 & 277\end{array}$

Combined

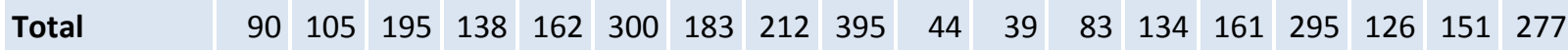

Source: Family Reunification Unit, Irish Naturalisation and Immigration Service, 2016.

TABLE A1.4 APPLICATIONS FOR FAMILY REUNIFICATION BY APPLICATION FROM BENEFICIARY OF INTERNATIONAL PROTECTION SPONSOR, 2011-2016

\begin{tabular}{|c|c|c|c|c|c|c|c|c|c|c|c|c|c|c|c|c|c|c|}
\hline \multirow{2}{*}{$\begin{array}{l}\text { Year } \\
\text { Status of } \\
\text { the } \\
\text { sponsor }\end{array}$} & \multicolumn{3}{|c|}{2011} & \multicolumn{3}{|c|}{2012} & \multicolumn{3}{|c|}{2013} & \multicolumn{3}{|c|}{2014} & \multicolumn{3}{|c|}{2015} & \multicolumn{3}{|c|}{$\begin{array}{l}2016 \text { (up to } \\
\text { an including } \\
24 / 11 / 2016 \text { ) }\end{array}$} \\
\hline & $\frac{0}{\sum^{10}}$ & है & एँ & $\frac{\frac{\omega}{\sigma}}{\Sigma}$ & $\begin{array}{l}\frac{\Phi}{\mathbb{N}} \\
\text { है } \\
\Psi\end{array}$ & 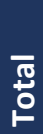 & $\frac{\frac{1}{10}}{\sum}$ & 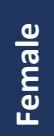 & 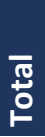 & $\frac{\frac{0}{10}}{\sum}$ & 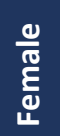 & 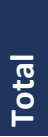 & $\frac{\frac{0}{10}}{\sum}$ & 造 & $\begin{array}{l}\overline{\text { एँ }} \\
\stackrel{\circ}{\circ}\end{array}$ & $\frac{\frac{10}{10}}{\sum}$ & 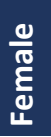 & 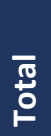 \\
\hline
\end{tabular}

Beneficiaries

of Intl.

$\begin{array}{lllllllllllllllllll}\text { protection - } & 287 & 227 & 514 & 194 & 271 & 465 & 177 & 218 & 395 & 266 & 227 & 493 & 238 & 305 & 543 & 32 & 35 & 67\end{array}$

Refugees

Beneficiaries

of Intl.

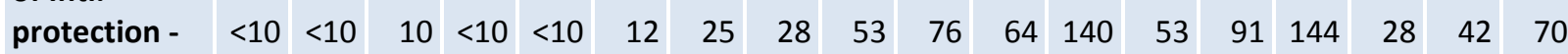

Subsidiary

Protection

Beneficiaries

of intl.

$\begin{array}{lllllllllllllllllll}\text { protection: } & 292 & 232 & 524 & 197 & 280 & 477 & 202 & 246 & 448 & 342 & 291 & 633 & 291 & 396 & 687 & 60 & 77 & 137\end{array}$

Combined

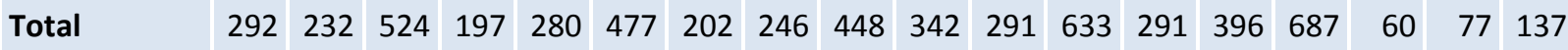

Source: Family Reunification Unit, Irish Naturalisation and Immigration Service, 2016. 
TABLE A1.5 SUCCESSFUL APPLICATIONS FOR FAMILY REUNIFICATION BY APPLICATION FROM BENEFICIARY OF INTERNATIONAL PROTECTION SPONSOR, 2011-2016

\begin{tabular}{|c|c|c|c|c|c|c|c|c|c|c|c|c|c|c|c|c|c|c|}
\hline \multirow{2}{*}{$\begin{array}{l}\text { Year } \\
\text { Status of } \\
\text { the } \\
\text { sponsor }\end{array}$} & \multicolumn{3}{|c|}{2011} & \multicolumn{3}{|c|}{2012} & \multicolumn{3}{|c|}{2013} & \multicolumn{3}{|c|}{2014} & \multicolumn{3}{|c|}{2015} & \multicolumn{3}{|c|}{$\begin{array}{l}2016 \text { (up to an } \\
\text { including } \\
24 / 11 / 2016 \text { ) }\end{array}$} \\
\hline & $\frac{\omega}{\frac{1}{\pi}}$ & 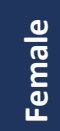 & $\begin{array}{l}\stackrel{\mathbb{0}}{o} \\
\stackrel{0}{2}\end{array}$ & $\frac{d}{\frac{d}{D}}$ & 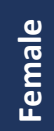 & $\begin{array}{l}\overline{0} \\
\stackrel{0}{\circ}\end{array}$ & $\frac{\frac{\omega}{\sigma 0}}{\Sigma}$ & 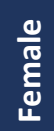 & 户ै & $\frac{\frac{\omega}{\sigma}}{\Sigma}$ & 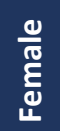 & 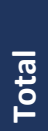 & $\frac{\omega}{\frac{10}{10}}$ & $\frac{\varrho}{\frac{O}{N}}$ & 홍 & $\frac{0}{\frac{0}{10}}$ & $\frac{\text { o }}{\text { है }}$ & $\begin{array}{l}\bar{\varpi} \\
\stackrel{0}{0}\end{array}$ \\
\hline
\end{tabular}

Beneficiaries

of Intl.

protection -

$\begin{array}{llllllllllllllllll}97 & 142 & 239 & 71 & 128 & 199 & 85 & 102 & 187 & 100 & 143 & 243 & 119 & 169 & 288 & 6 & 21 & 27\end{array}$

Refugees

Beneficiaries

of Intl.

\begin{tabular}{|l|l|l|l|l|l|l|l|l|l|l|l|l|l|l|l|l|l|l|}
\hline protection - & $<10$ & $<10$ & $<10$ & 0 & $<10$ & $<10$ & 10 & 15 & 25 & 50 & 44 & 94 & 28 & 49 & 77 & 17 & 16 & 33 \\
\hline
\end{tabular}

Subsidiary

Protection

Beneficiaries

of intl.

protection:

$\begin{array}{llllllllllllllllll}101 & 147 & 248 & 71 & 132 & 203 & 95 & 117 & 212 & 150 & 187 & 337 & 147 & 218 & 365 & 23 & 37 & 60\end{array}$

Combined

Total

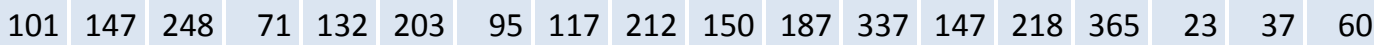

Source: Family Reunification Unit, Irish Naturalisation and Immigration Service, 2016.

TABLE A1.6 REJECTED APPLICATIONS FOR FAMILY REUNIFICATION BY APPLICATION FROM BENEFICIARY OF INTERNATIONAL PROTECTION SPONSOR, 2011-2016

\begin{tabular}{|c|c|c|c|c|c|c|c|c|c|c|c|c|c|c|c|c|c|c|}
\hline \multirow{2}{*}{$\begin{array}{l}\text { Year } \\
\text { Status of } \\
\text { the } \\
\text { sponsor }\end{array}$} & \multicolumn{3}{|c|}{2011} & \multicolumn{3}{|c|}{2012} & \multicolumn{3}{|c|}{2013} & \multicolumn{3}{|c|}{2014} & \multicolumn{3}{|c|}{2015} & \multicolumn{3}{|c|}{$\begin{array}{l}2016 \text { (up to anc } \\
\text { including } \\
24 / 11 / 2016 \text { ) }\end{array}$} \\
\hline & $\frac{\frac{\omega}{\sigma}}{\Sigma}$ & 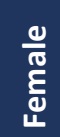 & 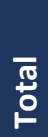 & $\frac{\frac{10}{10}}{\sum}$ & 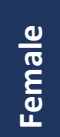 & $\begin{array}{l}\overline{\text { Dే }} \\
\stackrel{\circ}{\circ}\end{array}$ & $\frac{0}{\frac{10}{10}}$ & 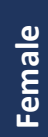 & $\begin{array}{l}\bar{\Phi} \\
\stackrel{0}{\circ}\end{array}$ & $\frac{0}{\frac{10}{10}}$ & 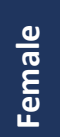 & $\begin{array}{l}\overline{\stackrel{0}{0}} \\
\stackrel{0}{\circ}\end{array}$ & $\frac{\frac{10}{10}}{\sum}$ & $\begin{array}{l}\frac{\mathscr{N}}{\mathrm{N}} \\
\frac{\mathrm{D}}{4}\end{array}$ & $\begin{array}{l}\overline{\text { एँ }} \\
\stackrel{\circ}{\circ}\end{array}$ & $\frac{\frac{0}{10}}{\Sigma}$ & 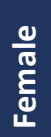 & 홍 \\
\hline
\end{tabular}

Beneficiaries

of intl.

$\begin{array}{lllllllllllllllllll}\text { protection - } & 114 & 123 & 237 & 99 & 118 & 217 & 72 & 91 & 163 & 106 & 117 & 223 & 92 & 96 & 188 & 11 & 8 & 19\end{array}$

Refugees

Beneficiaries

of intl.

\begin{tabular}{|l|l|l|l|l|l|l|l|l|l|l|l|l|l|l|l|l|l|l|}
\hline protection - & 0 & 0 & 0 & $<10$ & $<10$ & $<10$ & 12 & $<10$ & 20 & 25 & 18 & 43 & 19 & 28 & 47 & 14 & 23 & 37 \\
\hline
\end{tabular}

Subsidiary

Protection

Beneficiaries

of intl.

$\begin{array}{lllllllllllllllllll}\text { protection: } & 114 & 123 & 237 & 102 & 123 & 225 & 84 & 99 & 183 & 131 & 135 & 266 & 111 & 124 & 235 & 25 & 31 & 56\end{array}$

Combined

\begin{tabular}{|l|l|l|l|l|l|l|l|l|l|l|l|l|l|l|l|l|l|l} 
Total & 114 & 123 & 237 & 102 & 123 & 225 & 84 & 99 & 183 & 131 & 135 & 266 & 111 & 124 & 235 & 25 & 31 & 56 \\
\hline
\end{tabular}

Source: $\quad$ Family Reunification Unit, Irish Naturalisation and Immigration Service, 2016. 


\section{ANNEX II}

TABLE A2.1 VISA APPLICATIONS FOR FAMILY REASONS, 2011-2016

\begin{tabular}{|c|c|c|c|c|c|c|c|c|c|c|c|c|}
\hline & \multicolumn{2}{|c|}{2011} & \multicolumn{2}{|c|}{2012} & \multicolumn{2}{|c|}{2013} & \multicolumn{2}{|c|}{2014} & \multicolumn{2}{|c|}{2015} & \multicolumn{2}{|c|}{2016} \\
\hline & $\frac{\omega}{\sqrt{10}}$ & $\frac{\omega}{\mathbb{E}}$ & $\frac{\frac{\omega}{10}}{\sum}$ & $\begin{array}{l}\frac{0}{\mathrm{~N}} \\
\frac{1}{1} \\
\end{array}$ & $\frac{\frac{\omega}{10}}{\sum}$ & 高 & $\frac{\omega}{\frac{\omega}{10}}$ & 造 & $\frac{\frac{\omega}{10}}{\sum^{10}}$ & 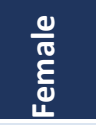 & $\frac{0}{\Sigma}$ & 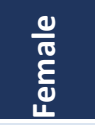 \\
\hline By Irish sponsor & 296 & 587 & 367 & 752 & 513 & 863 & 684 & 1,022 & 774 & 1,242 & 775 & 1,323 \\
\hline By EEA sponsor & 185 & 276 & 169 & 297 & 238 & 395 & 777 & 994 & 4,362 & 5,603 & 3,565 & 3,730 \\
\hline $\begin{array}{l}\text { By non-EEA } \\
\text { sponsor }\end{array}$ & 1,349 & 2,132 & 1,363 & 2,195 & 1,464 & 2,440 & 1,381 & 2,484 & 1,519 & 2,787 & 2,032 & 3,375 \\
\hline $\begin{array}{l}\text { Total applications } \\
\text { for visas for family } \\
\text { reasons }\end{array}$ & 1,830 & 2,995 & 1,899 & 3,244 & 2,215 & 3,698 & 2,842 & 4,500 & 6,655 & 9,632 & 6,372 & 8,428 \\
\hline $\begin{array}{l}\text { Total applications } \\
\text { for visas }\end{array}$ & 83,4 & & 88,3 & & 95,9 & & 101 & 582 & 115 & 590 & 124 & 225 \\
\hline
\end{tabular}

Source: Visa Section, Irish Naturalisation and Immigration Service, 2017.

TABLE A2.2 VISA APPLICATIONS FOR FAMILY REASONS GRANTED, 2011-2016

\begin{tabular}{|c|c|c|c|c|c|c|c|c|c|c|c|c|}
\hline & \multicolumn{2}{|c|}{2011} & \multicolumn{2}{|c|}{2012} & \multicolumn{2}{|c|}{2013} & \multicolumn{2}{|c|}{2014} & \multicolumn{2}{|c|}{2015} & \multicolumn{2}{|c|}{2016} \\
\hline & $\frac{0}{\frac{0}{\pi}}$ & 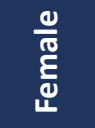 & $\frac{\omega}{\Sigma}$ & 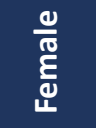 & $\frac{0}{N^{10}}$ & 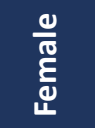 & $\frac{\mathscr{\omega}}{\mathbb{N}^{10}}$ & 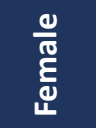 & $\frac{0}{N^{10}}$ & $\frac{\omega}{\frac{\omega}{D}}$ & $\frac{\omega}{\sqrt{10}}$ & $\begin{array}{l}\frac{0}{\mathrm{~N}} \\
\text { है } \\
\stackrel{1}{L}\end{array}$ \\
\hline By Irish sponsor & 227 & 482 & 270 & 618 & 346 & 672 & 414 & 745 & 595 & 1008 & 484 & 849 \\
\hline By EEA sponsor & 140 & 222 & 131 & 245 & 214 & 369 & 590 & 789 & 1285 & 1981 & 585 & 962 \\
\hline $\begin{array}{l}\text { By non-EEA } \\
\text { sponsor }\end{array}$ & 1,132 & 1,823 & 1,206 & 1,984 & 1,230 & 2,116 & 1,120 & 2,060 & 1,329 & 2,429 & 1,770 & 2,888 \\
\hline $\begin{array}{l}\text { Total } \\
\text { applications for } \\
\text { visas for family } \\
\text { reasons granted }\end{array}$ & 1,499 & 2,527 & 1,607 & 2,847 & 1,790 & 3,157 & 2,124 & 3,594 & 3,209 & 5,418 & 2,839 & 4,699 \\
\hline $\begin{array}{l}\text { Total } \\
\text { applications for } \\
\text { visas granted }\end{array}$ & 74, & 667 & 79,3 & & 86 & & 90 & & 97, & & 104 & 572 \\
\hline
\end{tabular}

Source: Visa Section, Irish Naturalisation and Immigration Service, 2017. 
TABLE A2.3 VISA APPLICATIONS FOR FAMILY REASONS REJECTED, 2011-2016

\begin{tabular}{|c|c|c|c|c|c|c|c|c|c|c|c|c|}
\hline \multirow[b]{2}{*}{ Family reasons } & \multicolumn{2}{|c|}{2011} & \multicolumn{2}{|c|}{2012} & \multicolumn{2}{|c|}{2013} & \multicolumn{2}{|c|}{2014} & \multicolumn{2}{|c|}{2015} & \multicolumn{2}{|c|}{2016} \\
\hline & $\frac{\omega}{\Sigma}$ & 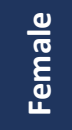 & $\frac{0}{\sum}$ & $\frac{0}{\frac{0}{0}}$ & $\frac{\frac{\omega}{\sigma}}{\Sigma}$ & 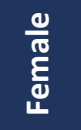 & $\frac{\stackrel{\omega}{J}}{\Sigma}$ & $\frac{\infty}{\frac{1}{\pi}}$ & $\frac{0}{\frac{0}{10}}$ & $\frac{0}{\stackrel{0}{0}}$ & $\frac{\omega}{\tilde{N}}$ & $\frac{\omega}{\frac{\omega}{D}}$ \\
\hline By Irish sponsor & 55 & 89 & 59 & 60 & 145 & 156 & 154 & 136 & 177 & 209 & 149 & 182 \\
\hline By EEA sponsor & 32 & 42 & 45 & 42 & 22 & 33 & 57 & 52 & 247 & 241 & 215 & 183 \\
\hline By non-EEA sponsor & 193 & 262 & 159 & 268 & 237 & 288 & 165 & 250 & 96 & 187 & 70 & 152 \\
\hline $\begin{array}{l}\text { Total applications for } \\
\text { visas for family reasons } \\
\text { refused }\end{array}$ & 280 & 393 & 263 & 370 & 404 & 477 & 376 & 438 & 520 & 637 & 434 & 517 \\
\hline $\begin{array}{l}\text { Total applications for } \\
\text { visas refused }\end{array}$ & & & & & & & & & & & & 08 \\
\hline
\end{tabular}

Source: Visa Section, Irish Naturalisation and Immigration Service, 2017. 


\section{ANNEX III}

TABLE A3.1 TOP TEN NATIONALITIES OF APPLICANT FAMILY MEMBERS FOR VISAS FOR FAMILY REASONS, 2016 (NON-EEA SPONSOR)

\begin{tabular}{|l|c|}
\hline \multicolumn{1}{|c|}{ Nationality } & No. of applications \\
\hline India & 1,872 \\
\hline Pakistan & 707 \\
\hline Saudi Arabia & 547 \\
\hline People's Republic of China & 347 \\
\hline Egypt & 295 \\
\hline Sudan & 169 \\
\hline Russian Federation & 139 \\
\hline Iraq & 123 \\
\hline Philippines & 95 \\
\hline Syrian Arab Republic & 81 \\
\hline All other nationalities & 1,032 \\
\hline Total & 5,407 \\
\hline
\end{tabular}

Source: Visa Section, Irish Naturalisation and Immigration Service, 2017.

TABLE A3.2 TOP TEN NATIONALITIES OF PERSONS GRANTED VISAS FOR FAMILY REASONS, 2016 (NON-EEA SPONSOR)

\begin{tabular}{|l|c|}
\hline \multicolumn{1}{c|}{ Nationality } & No. of applications \\
\hline India & 1,785 \\
\hline Saudi Arabia & 529 \\
\hline Pakistan & 411 \\
\hline People's Republic of China & 332 \\
\hline Egypt & 272 \\
\hline Sudan & 166 \\
\hline Russian Federation & 133 \\
\hline Ukraine & 72 \\
\hline Iraq & 71 \\
\hline Syrian Arab Republic & 71 \\
\hline All other nationalities & 816 \\
\hline Total & 4,658 \\
\hline
\end{tabular}

Source: Visa Section, Irish Naturalisation and Immigration Service, 2017. 
TABLE A3.3 TOP TEN NATIONALITIES OF PERSONS REFUSED VISAS FOR FAMILY REASONS, 2016 (NON-EEA SPONSOR)

\begin{tabular}{l|c}
\hline \multicolumn{1}{c|}{ Nationality } & No. of applications \\
\hline Bangladesh & 43 \\
\hline India & 35 \\
\hline Pakistan & 18 \\
\hline Nigeria & 18 \\
\hline Ghana & 9 \\
Nepal & 9 \\
\hline Saudi Arabia & 8 \\
\hline Philippines & 8 \\
\hline Egypt & 7 \\
\hline Ukraine & 7 \\
\hline All other nationalities & 60 \\
\hline Total & 222 \\
\hline
\end{tabular}

Source: Visa Section, Irish Naturalisation and Immigration Service, 2017. 
EMN Ireland,

Economic and Social

Research Institute,

Whitaker Square,

Sir John Rogerson's Quay,

Dublin 2, Ireland

Telephone +353 18632000

Email emn.ireland@esri.ie

Web www.emn.ie / www.esri.ie

Twitter @ESRIDublin 